\title{
Wind-Driven Cross-Equatorial Flow in the Indian Ocean
}

\author{
M. Dolores PÉREZ-Hernández And Alonso HernándeZ-Guerra \\ Instituto Universitario de Oceanografía y Cambio Global, Universidad de Las Palmas de Gran Canaria, Las Palmas de \\ Gran Canaria, Spain
}

TERRENCE M. JOYCE

Department of Physical Oceanography, Woods Hole Oceanographic Institution, Woods Hole, Massachusetts

PEDRo Vélez-Belchí

Instituto Español de Oceanografia, General Gutiérrez 4, Santa Cruz de Tenerife, Spain

(Manuscript received 12 February 2012, in final form 13 August 2012)

\begin{abstract}
Meridional velocity, mass, and heat transport in the equatorial oceans are difficult to estimate because of the nonapplicability of the geostrophic balance. For this purpose a steady-state model is utilized in the equatorial Indian Ocean using NCEP wind stress and temperature and salinity data from the World Ocean Atlas 2005 (WOA05) and Argo. The results show a Somali Current flowing to the south during the winter monsoon carrying $-11.5 \pm 1.3 \mathrm{~Sv}\left(1 \mathrm{~Sv} \equiv 10^{6} \mathrm{~m}^{3} \mathrm{~s}^{-1}\right)$ and $-12.3 \pm 0.3 \mathrm{~Sv}$ from WOA05 and Argo, respectively. In the summer monsoon the Somali Current reverses to the north transporting $16.8 \pm 1.2 \mathrm{~Sv}$ and $19.8 \pm 0.6 \mathrm{~Sv}$ in the WOA05 and Argo results. Transitional periods are considered together and in consequence, there is not a clear Somali Current present in this period. Model results fit with in situ measurements made around the region, although Argo data results are quite more realistic than WOA05 data results.
\end{abstract}

\section{Introduction}

The Indian Ocean has the greatest seasonal variability of all oceans because of the influence of the winter and summer monsoons. Both monsoons represent very different wind and ocean circulation conditions (Reppin et al. 1999; Grumet et al. 2002; Tomczak and Godfrey 2003). The winter or northeast monsoon prevails during the months of December to March (Schott et al. 1990; Donguy and Meyers 1995; Grumet et al. 2002; Tomczak and Godfrey 2003). During this period, the trade winds of the Northern Hemisphere (Fig. 1a) cover the northern Indian Ocean down to approximately $10^{\circ} \mathrm{S}$, generating the wind-driven southward Somali Current, which constitutes the western boundary current of the Indian Ocean (Reppin et al. 1999; Schott and McCreary 2001). The interior flow is considered to flow northward during this season (Levitus 1988; Schott and McCreary 2001).

Corresponding author address: Dr. Terrence M. Joyce, Woods Hole Oceanographic Institution, Woods Hole, MA 02543.

E-mail: tjoyce@whoi.edu
The summer or southwestern monsoon prevails during the months of June-September (Schott and McCreary 2001; Grumet et al. 2002; Tomczak and Godfrey 2003; Shenoi et al. 2009). This monsoon is characterized by strong southwesterly winds (Fig. 1c), which are considered to be a northward incursion of the Southern Hemisphere trade winds (Tomczak and Godfrey 2003). This strong wind occupies the whole Indian Ocean, and the Somali Current, because of its wind-driven character, and flows northward (Reppin et al. 1999; Grumet et al. 2002). Over the rest of the equatorial area, a southward transport is found (Levitus 1988; Schott and McCreary 2001).

In between both monsoons, two transitional periods occur. The first involves the months of April and May and the second occurs in October and November (Reppin et al. 1999; Murty et al. 2000; Schott and McCreary 2001; Tomczak and Godfrey 2003; Shenoi et al. 2009). During these periods the meridional component of the wind is weak and the zonal component is strong (Hastenrath and Lamb 2004). The first transitional period marks the transition from the winter to the summer monsoon. At this time the meridional, cross-equatorial flow is 


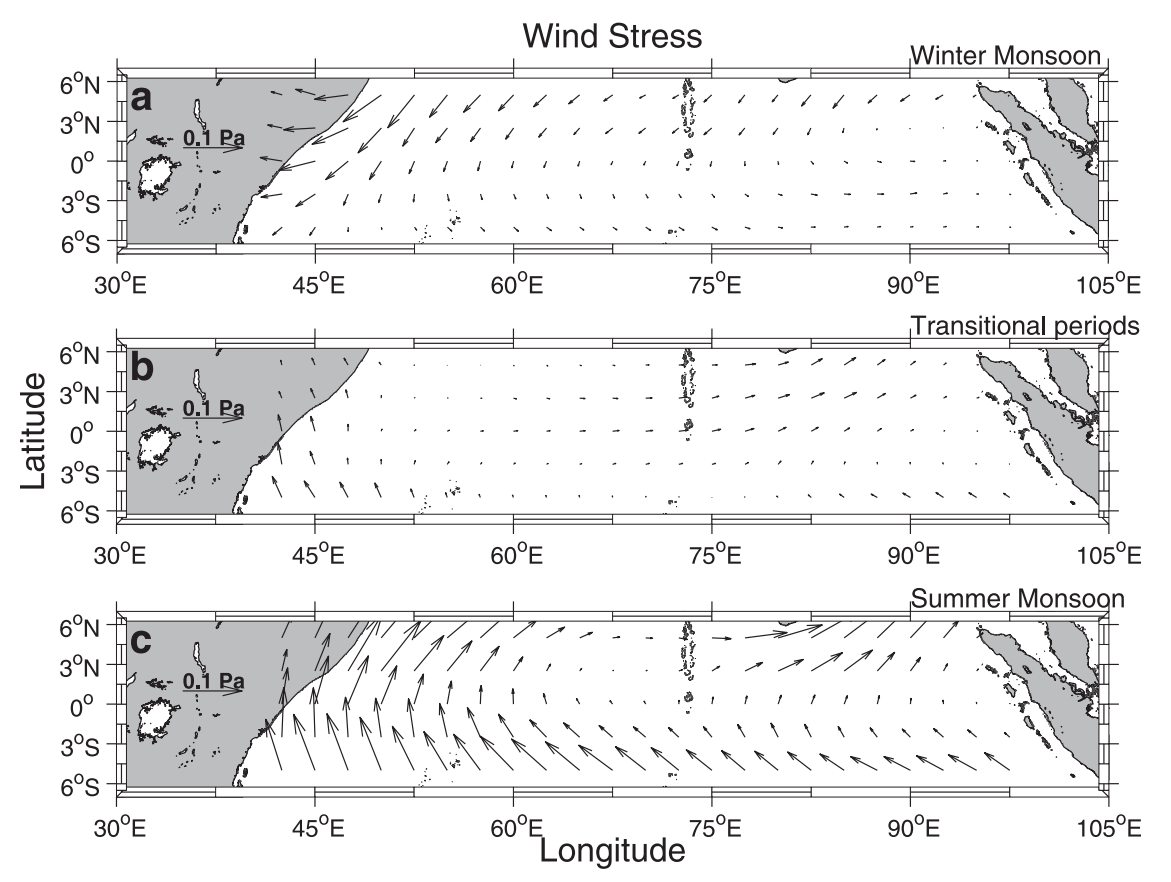

FIG. 1. Wind stress field during the (a) winter monsoon, (b) transitional periods, and (c) summer monsoon.

dominated by the Somali Current, which is still flowing southward (Donguy and Meyers 1995). The second transitional period takes place between the summer and winter monsoons. In these months, the Somali Current continues the northward summer monsoon flow, carrying water across the equator (Donguy and Meyers 1995). In this study, we will refer as "season" each of the monsoons and the transitional periods.

The oceanic regime in the Indian Ocean has given rise to several studies that may be differentiated by area and/ or period (Duing et al. 1980; Leetmaa et al. 1980; Luyten et al. 1980; Schott and Quadfasel 1982; Schott et al. 1990; Donguy and Meyers 1995; Reppin et al. 1999; Murty et al. 2000). Schott and McCreary (2001) present a review of the previous studies carried out in this ocean. It is worth mentioning that the zonal current in the equatorial Indian Ocean has been intensively studied (Wyrtki 1973; Knox 1976; Reppin et al. 1999; Hastenrath 2000; Sengupta et al. 2007), however, studies of the crossequatorial flow in the Indian Ocean have been focused on the western boundary Somali Current (Leetmaa et al. 1980; Duing et al. 1980; Leetmaa et al. 1982; Schott et al. 1990; Grumet et al. 2002). Most have been in situ studies done with current meters and Lagrangian drifters at different periods, with the aim of studying the intensity and the reversal of the Somali Current.

In the study of the cross-equatorial circulation, Joyce (1988a,b) proposed that wind and dynamic height variations are associated with a dynamical balance, which permits seasonal varying a cross-equatorial flow. This idea was based on the Sverdrup (1947) study, which suggested that the meridional pressure gradient $P_{y}$ could be balanced by a functional of the meridional wind stress $\tau^{y}$. The resulting steady-state equations transform the initial Navier-Stokes equations by expanding them into a Taylor series at the equator. These equations take into account the equatorial $\beta$ plane, which considers the Coriolis force as $f=\beta y$, with $\beta=f_{y}$ at the equator and $y$ the meridional axis.

The equations proposed by Joyce (1988a) are the following:

$$
\begin{aligned}
\tau_{z}^{y} & =P_{y}, \\
-\beta \tilde{v} & =\left(\tau_{y z}^{x}-\tau_{x z}^{y}\right) / \rho_{0}=\left(\tau_{y z}^{x}-P_{x y}\right) / \rho_{0}, \quad \text { and } \\
\tilde{v} & =v\left(1-u_{y y} / \beta\right) .
\end{aligned}
$$

Equation (1) shows that the vertical variation of the meridional wind stress $\tau_{z}^{y}$ balances the meridional pressure gradient $P_{y}$. Equation (2) reflects the Sverdrup balance with a surrogate meridional velocity $\tilde{v}$, and Eq. (3) is just the relation between the meridional velocity $v$ and the surrogate meridional velocity obtained by (2). Here, $P_{x y}$ is used to compute velocities and transport from WOA05 and Argo data. These are linearized equations that consider $u_{y}=0$ and $w_{y}=0$ at the equator. This means that the equator is an extremum in zonal and 
vertical velocities. Unique to the Indian Ocean, strong zonal equatorial velocities occur during the transitional periods called Wyrtki jets (Wyrtki 1973). During other seasons, zonal currents decrease significantly to near zero (Knox 1976). The extremum in vertical velocity is more difficult to demonstrate because of the lack of in situ studies. Several pieces of evidence have shown that, in contrast to the other equatorial regimes, the upwelling at the equator in the Indian Ocean is absent and therefore $w=0$ (Schott and McCreary 2001; Schott et al. 2002; Tomczak and Godfrey 2003; Diansky et al. 2006). Following Eq. (3), the meridional velocity can be obtained by dividing the surrogate meridional velocity by the factor $\left(u_{y y} / \beta\right)$. As already mentioned, during the monsoons, the zonal velocity is weak and the term $\left(1-u_{y y} / \beta\right)$ is not significantly different from one. During the transitional periods, Wyrtki (1973) describes a zonal equatorial jet with velocities higher than $50 \mathrm{~cm} \mathrm{~s}^{-1}$, centered at the equator, with a length scale of $500 \mathrm{~km}$ and centered at $80 \mathrm{~m}$. At $90^{\circ} \mathrm{E}$, Masumoto et al. (2005) shows a Wyrtki jets of $>40 \mathrm{~cm} \mathrm{~s}^{-1}$ and an undercurrent of $\sim 40 \mathrm{~cm} \mathrm{~s}^{-1}$ centered at $200 \mathrm{~m}$. Taking a Gaussian profile for the zonal velocity, centered at the equator, with an length scale of $250 \mathrm{~km}$, and a maximum of $40 \mathrm{~cm} \mathrm{~s}^{-1}$ at the equator, the factor $u_{y y} / \beta$ is 0.28 . Then, also during the transtional periods, the effect of the term that modifies the meridional velocity $v$ would be of limited significance.

The aim of this paper is to investigate the Indian Ocean cross-equatorial meridional velocity and transport of volume and heat per season using the above quasi-steady wind-driven model proposed by Joyce (1988a,b). For this purpose, we use wind stress from the National Centers for Environmental Prediction (NCEP) reanalysis project, climatological data from the World Ocean Atlas 2005 (WOA05) and Argo data. WOA05 is used in two ways: as the first guess for analyzing objectively the Argo data and as basic hydrographic data. Results using WOA05 and objectively analyzed Argo data will be compared. After a presentation of data and methods in section 2, we will describe the results in section 3 attending to the confidence of the model and the estimation of the meridional volume transport, meridional velocity, and the meridional heat transport.

\section{Data and methods}

Wind and Argo data for a 7-yr period (2003-09) and climatological data from WOA05 are collected for the geographic area between $44.5^{\circ}$ and $96^{\circ} \mathrm{E}$. The westernmost and easternmost longitudes are imposed by the slant of the Somali and Sumatra coasts. The latitude range is $2.5^{\circ}$ and $4^{\circ}$ at both sides of the equator, for wind and hydrographic data, respectively. The average of 7 years of wind data avoids the strong interannual variability found in the Indian equatorial ocean (Barnett 1983; Reverdin 1987). Because of the strong seasonal variability in the equatorial Indian Ocean and following the Joyce (1988b) seasonal study in the equatorial Atlantic Ocean, we have considered three different seasons to carry out this study: winter monsoon (DecemberMarch), summer monsoon (June-September), and transitional periods. Transitional periods are considered together because there are not enough Argo profiles to consider them separately.

The wind data come from the NCEP reanalysis project from the National Oceanic and Atmospheric Administration (NOAA) (September 2010, http://www.esrl.noaa. gov/psd/data/reanalysis/reanalysis.shtml). This project produces new analyses of atmospheric conditions using historical data. Wind velocity data were downloaded every $2.5^{\circ}$ of latitude and longitude per month and year. These velocities were seasonally averaged. Wind stress (Fig. 1) is calculated using the quadratic relationship proposed by Large and Pond (1981).

Hydrographic data come from a climatology (WOA05, http://www.nodc.noaa.gov/OC5/WOA05/pr_woa05.html) and the Argo International Program. The Argo Project (http://www.argo.net) consists of a fleet of more than 3000 profilers across the World Ocean. These profilers drift at pressures of 1500 or 1000 dbar and every 10 days they descend to 2000 dbar to measure salinity and temperature at discrete levels in the way up to the surface were recorded data are telemeted (Roemmich et al. 2009).

All available good quality Argo data in the equatorial Indian Ocean $\left(6^{\circ} \mathrm{S}-6^{\circ} \mathrm{N}, 38^{\circ}-105^{\circ} \mathrm{E}\right)$ from January 2003 to March 2010 were downloaded in April 2010. Besides the real-time quality control, and the delayed mode quality control provide by the Argo data system (Argo Data Management Team 2002), all data passed a more stringent quality control procedure developed by VélezBelchí et al. (2010). This quality control includes visual inspection of all the temperature and salinity profiles used, and comparing them with their neighboring profiles by means of objective analysis. All floats with suspicious profiles either in temperature or salinity were inspected individually. Those profiles from floats with suspicious behavior, or on the Argo gray list (Argo Data Management Team 2002), were excluded from the dataset. As a result, 7379 from an initial set of more than 12000 profiles within the region of interest were used (Fig. 2).

After the quality control procedure, the Argo data are objectively interpolated onto a hypothetical zonal and meridional "region" at the equator every $2.5^{\circ}$ in 


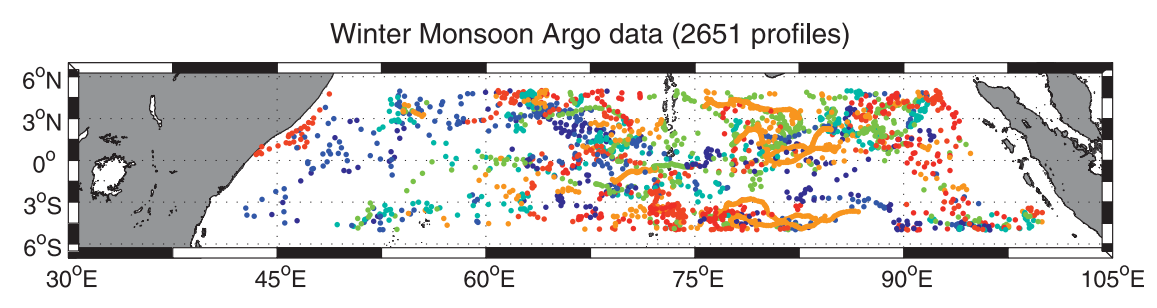

Transitional Period Argo data (2453 profiles)

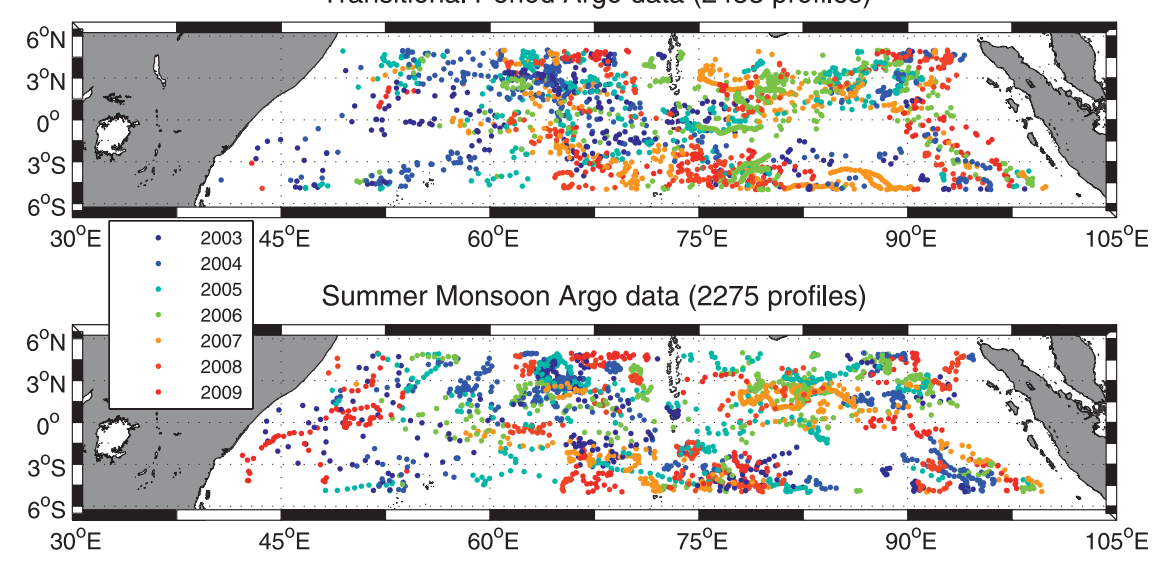

FIG. 2. Distribution of Argo floats over the equatorial Indian Ocean in each season. Colors represent the year of each profile.

longitude and latitude using optimal statistical interpolation. The seasonal climatological temperature and salinity data from the WOA05 are used as a first guess to ensure that the anomaly field (data minus climatology) is a stationary, zero-mean random function of the location.

The parameters for the objective analysis are computed using the anomalies from the 7379 Argo profiles (2651 for the winter monsoon, 2453 for the transitional periods and 2275 for the summer monsoon) following the technique described by Pedder (1993) and Gomis and Pedder (2005), assuming a Gaussian correlation model, and uncorrelated noise. The correlation scale for the anomalies is 50 nautical miles (nm) and the noiseto-signal ratio is 2 . Low-pass spatial filtering, with a cutoff length scale of $200 \mathrm{~nm}$, is carried out to filter out unwanted length scales introduced by the Gaussian correlation model, which have, in Fourier space, an infinitely long tail for small scales. Additionally, a sensitivity study was carried out modifying these parameters within the uncertainty of the method. The results obtained did not significantly change.

The large amount of data and the 7-yr span of the observations allow ocean noise, always present in single hydrographic sections, to be greatly reduced. Noise is defined as any unresolved scale, and in transoceanic sections it is mainly attributed to eddies (Pedder 1993; Gomis and Pedder 2005). In this sense, the synthetic
Argo section is less affected by eddy noise than the hydrographic sections since this statistical approach is designed to minimize the noise-to-signal ratio. The methodology has been previously used by Fraile-Nuez and Hernández-Guerra (2006) and Hernández-Guerra et al. (2010), and was successfully validated against ship based CTD hydrographic sections by Vélez-Belchí et al. (2010). The latter authors also demonstrated the robustness of the method with respect to changes in the climatology used for the first guess.

The error in each level of the synthetic temperature and salinity Argo sections is estimated using a bootstrap analysis (Efron and Tibshirani 1993). This method assumes that the data, the Argo measurements, at each level (101 levels, from 10 to 2000 dbars following the standard Argo levels) are considered just a sample of a variable with unknown distribution of probability. If this distribution was precisely known, mean values and errors could be accurately calculated. The bootstrap method estimates this probability distribution by resampling the horizontal distribution of data. If the original record consists of $N$ data values (positions and temperature/salinity), a new sample is constructed by selecting, in a random way, $N$ data values allowing repetition. The difference between the original data distribution and the new sample is that some data values are repeated in the second and, therefore, some original data values are not included in the new sample. After the 

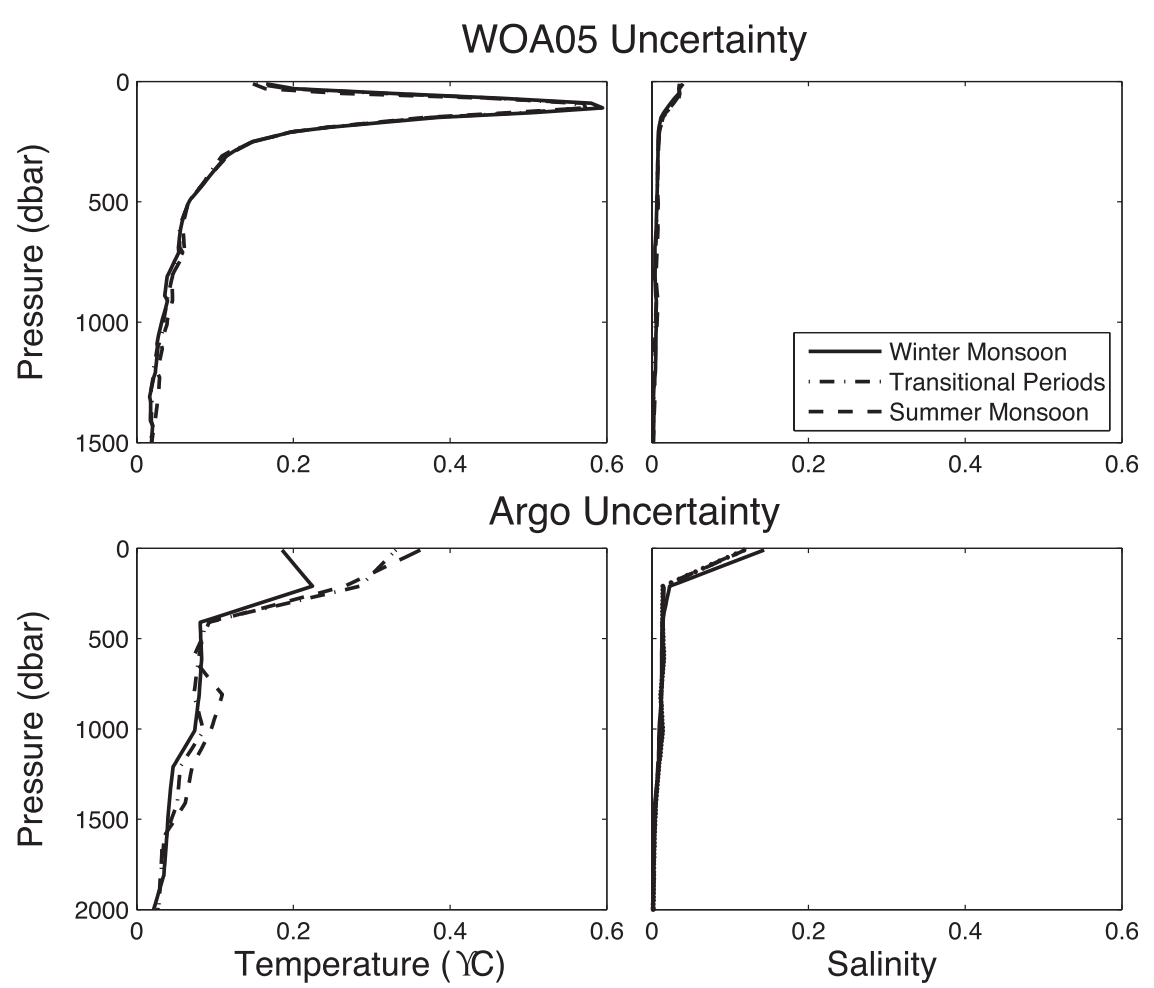

FIG. 3. (left) Temperature and (right) salinity vertical uncertainties for (top) WOAO5 and (bottom) Argo.

new sample is selected, objective analysis is applied in the same way as to the original distribution of data. As result, a set of 100 objective analyzed horizontal fields of temperature and salinity at each level are obtained. The difference between the original objective analyzed horizontal field and the 100 samples gives the standard error of the mean, an estimate of the reliability of analysis and can be considered the error of the method used to obtain the Argo synthetic sections. This uncertainty of the temperature and salinity fields is shown in Fig. 3. Similar results are obtained using 1000 simulations.

Once the uncertainty in the synthetic temperature and salinity Argo sections is obtained from the objective analysis, an uncertainty in velocity, mass and heat transport is estimated using a Monte Carlo method (Hammersley and Handscomb 1975). For each level, a sample of 1000 values of $x_{i}$ (temperature and salinity) are simulated in the range $x-\delta x<x_{i}<x+\delta x, x$ being the value obtained from the objective analysis for each level and $\delta x$ its uncertainty according to Fig. 3 . With these new values, a sample of 1000 velocities, mass, and heat transports are calculated and used to estimate their uncertainties.

The WOA05 data are composed of the climatological mean monthly salinity and temperature data from the surface down to $1500 \mathrm{~m}$ and annual data from 1500 to
$2000 \mathrm{~m}$. Thus, WOA05 data are only used down to $1500 \mathrm{~m}$ to estimate volume and heat transport, and meridional velocity, in each season, from the quasi-steady model. In Fig. 3 the standard error of the statistical mean downloaded from WOA05 is shown. WOA05 velocity, mass, and heat transport uncertainty is estimated using a Monte Carlo method as in the Argo data.

To evaluate the steady-state model, we compute meridional and zonal gradients. Meridional gradients are calculated by least squares fits between $-2.5^{\circ}$ and $2.5^{\circ}$. When approaching the western boundary, and due to the slant of the Somali coast, the meridional gradient is reduced to the interval $-1.5^{\circ}$ to $1.5^{\circ}$. Zonal gradients are estimated by differencing wind stress and dynamic height over $2.5^{\circ}$ of longitude.

Figure 4 shows objectively analyzed vertical sections of temperature (left column) and salinity (right column) over the equatorial Indian Ocean for each season. Above the seasonal thermocline ( $\sim 200 \mathrm{dbar})$, a shallow layer of anomalous temperature and salinity values is found. This is due to seasonal heating, evaporation, and in the east, from advection of low salinity waters from the Bay of Bengal and Indonesian Throughflow. From $70^{\circ} \mathrm{E}$ to the eastern boundary, low salinities and high temperatures indicate the presence of Bay of Bengal Water (BBW), which spreads as a thick layer of $\sim 100 \mathrm{dbar}$ 

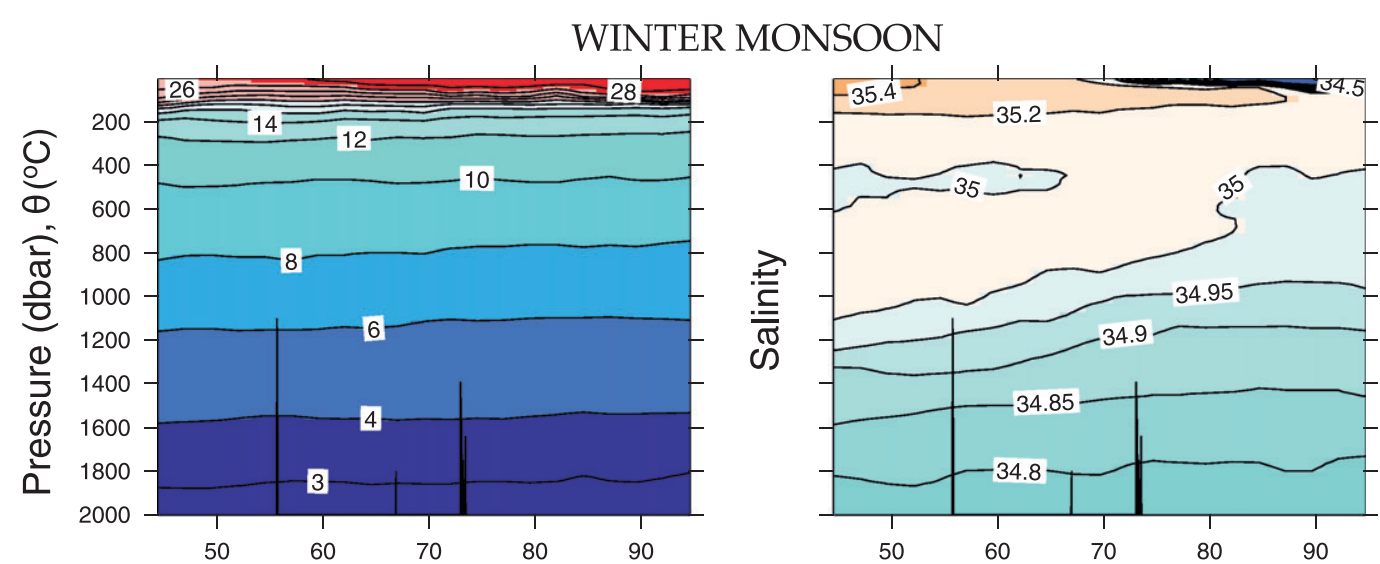

TRANSITIONAL PERIODS
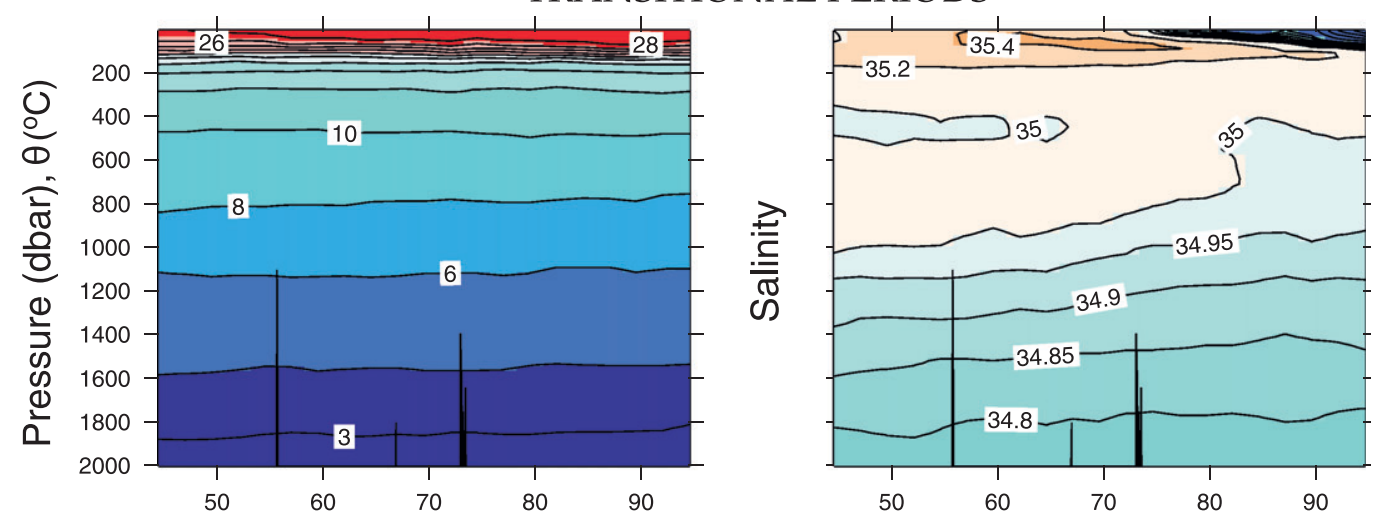

SUMMER MONSOON
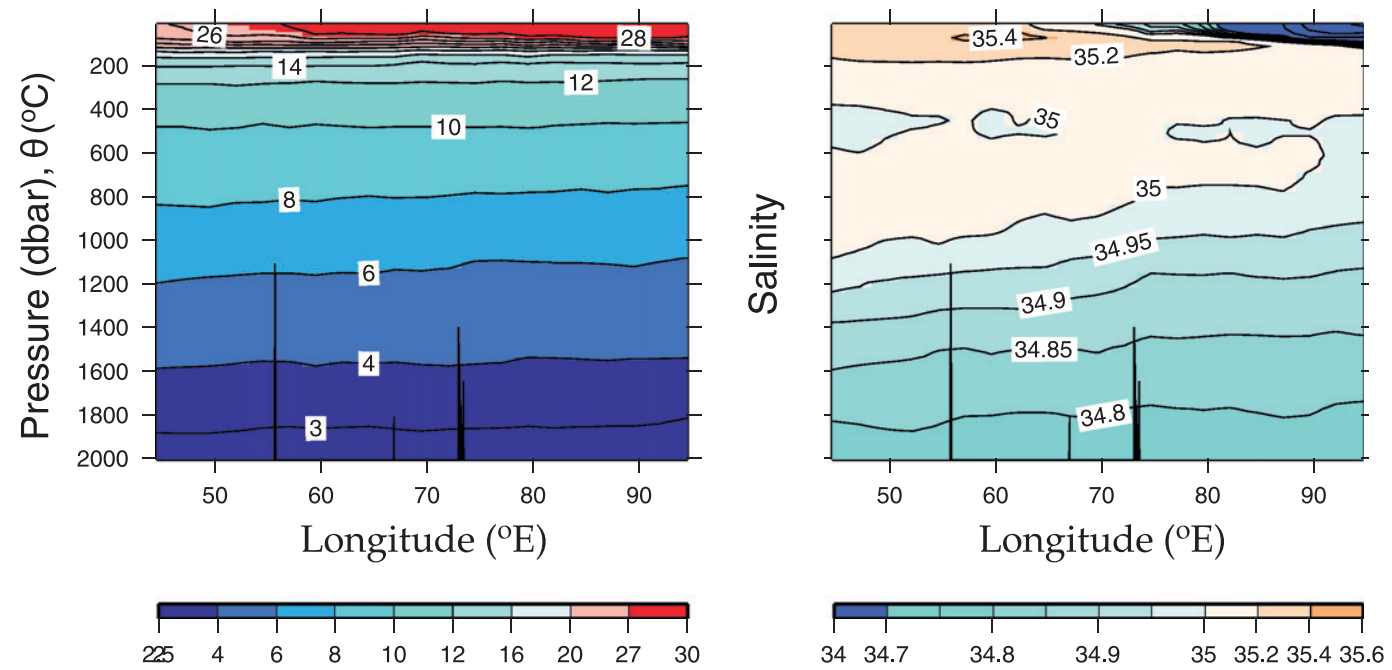

FIG. 4. (left) Temperature and (right) salinity vertical sections in each season from the objectively analyzed Argo data.

(You and Tomczak 1993; Tomczak and Godfrey 2003). Below the seasonal thermocline, Indian Central Water (ICW) and Australasian Mediterranean Water (AAMW) are found. ICW dominates practically the whole section with salinities between 35 and 35.2, being fresher to the east. The AAMW enters from the Indonesian Throughflow as a front into the equatorial area, with temperatures around $8^{\circ} \mathrm{C}$ and salinities below 35 in a depth range from $\sim 300$ to $\sim 1100$ dbar (Tomczak and Large 1989; You and Tomczak 1993). It is clearly seen in 
the vertical section of salinity that this water mass forms patches at the depth of ICW in the western side of the basin. Below the 1500 dbar, Indian Deep Water (IDW) is observed with salinities around 34.8 (Tomczak and Godfrey 2003).

\section{Results}

\section{a. Model}

The quasi-steady state of this stationary model is explored with seasonal data like in Joyce (1988b). As stated in Eq. (1), a balance is expected between the meridional pressure gradients and the frictional forces created by cross-equatorial winds at the equator. To examine the quasi-stationary state of this balance, the meridional pressure gradients at the surface relative to 1000-m depth from WOA05 and Argo data, and the meridional wind stress at each season, are presented in Fig. 5. This figure shows that the meridional wind stress is negative (winter monsoon) or positive (transitional periods and summer monsoon) throughout the basin with weaker wind stress on the eastern boundary. The meridional gradient of the dynamic height at the surface (10 dbar) relative to 1000 dbar roughly follows the pattern of the meridional wind stress. Figure 5 shows a high mesoscale signal in both databases, more evident in the Argo data. Although objective analysis reduces the mesoscale signal, it is still present in the data since the Indian equator is an energetic area populated by eddies (Maximenko et al. 2009).

The vertically-integrated version of Eq. (1) is explored in Fig. 6 where different reference pressures are chosen to integrate the gradient of the dynamic height and compared to the meridional wind stress. In this figure, the mesoscale signal is clear in the Argo data and, to a lesser extent, in the WOA05 data. The winter monsoon (Figs. 6a1,b1) presents a negative and increasing meridional wind stress from the eastern boundary to roughly $50^{\circ} \mathrm{E}$. This pattern observed is the integrated meridional gradient of the dynamic height, although a mesoscale signal is clearly seen in the WOA05 and Argo data. At about $50^{\circ} \mathrm{E}$, there is a change in the slope of the meridional wind stress that is observed in the meridional gradient of the dynamic height from the WOA05 data. This change is also present in the Argo data, although the presence of the eddy signal makes it difficult to confirm. For the transitional periods (Figs. 6a2,b2), meridional wind stress is weak from the eastern boundary to $50^{\circ} \mathrm{E}$, where a stronger positive wind stress is seen. The integrated meridional gradient of the dynamic height roughly follows this behavior with a very strong eddy field in the Argo data. The meridional wind stress of the summer monsoon (Figs. 6a3,b3) nearly resembles that of the winter monsoon but is reversed. On this occasion, the wind stress is positive and monotonically increasing from $70^{\circ} \mathrm{E}$ to the western boundary. The integrated meridional gradient of the dynamic height roughly follows this same pattern. From above, we can assert that the model can be applied in the equatorial Indian Ocean.

As the model mainly depends on wind stress, the most plausible source of systematic errors comes from the chosen wind stress data product. Appendix shows results from Quick Scatterometer (QuikScat; QS) wind data, collected from satellite, and compares it with the estimations from NCEP wind product. This comparison shows that QS wind presents higher volume transports than NCEP winds for the equatorial Indian Ocean. This behavior has been previously observed by Goswami and Sengupta (2003) and Hernández-Guerra et al. (2010).

\section{b. Volume transport}

Following Eq. (2), Fig. 7 shows both components of the wind forcing and the total of the volume transport from the wind stress curl together with the accumulated volume transport. Figures 7a1-3 show that the component $\tau_{x}^{y}$ fluctuates about zero for the three seasons, just as it does in the equatorial Pacific and Atlantic Oceans (Joyce 1988a,b). The integrated transport for this component of the wind stress curl is $0.5 \mathrm{~Sv}\left(1 \mathrm{~Sv} \equiv 10^{6} \mathrm{~m}^{3} \mathrm{~s}^{-1}\right)$, $-1.1 \mathrm{~Sv}$, and $-3.1 \mathrm{~Sv}$ for the winter monsoon, transitional periods, and summer monsoon, respectively. It is worth mentioning that this component of the wind stress curl changes sign when approaching the western boundary, this is more apparent for the winter and summer monsoons. Figures $7 \mathrm{~b} 1, \mathrm{~b} 3$ show that the equatorial $-\tau_{y}^{x}$ component for the winter monsoon has a northward direction while in the summer monsoon is southward. The accumulated volume transport for this component of the wind stress curl in the summer monsoon is larger $(-7.2 \mathrm{~Sv})$ than in the winter monsoon $(3.0 \mathrm{~Sv})$. The transitional periods have a very weak southward-integrated volume transport of $-1.0 \mathrm{~Sv}$; this transport is located in the eastern half of the Indian Ocean (Fig. 7b2). The total wind stress curl integrated westward from the eastern boundary shows a roughly monotonic increase (absolute value) during the winter and summer monsoons. Near the western boundary an inflection of the total volume transport is observed. For the transitional periods, only the eastern and western boundaries show a significant volume transport. To achieve the zero volume fluxes across the equator, the imbalance that is the total wind stress curl for each season has to be added to the western boundary current, the Somali Current. This assumes that the higher-order dynamics not considered in the model are found at the western boundary. 


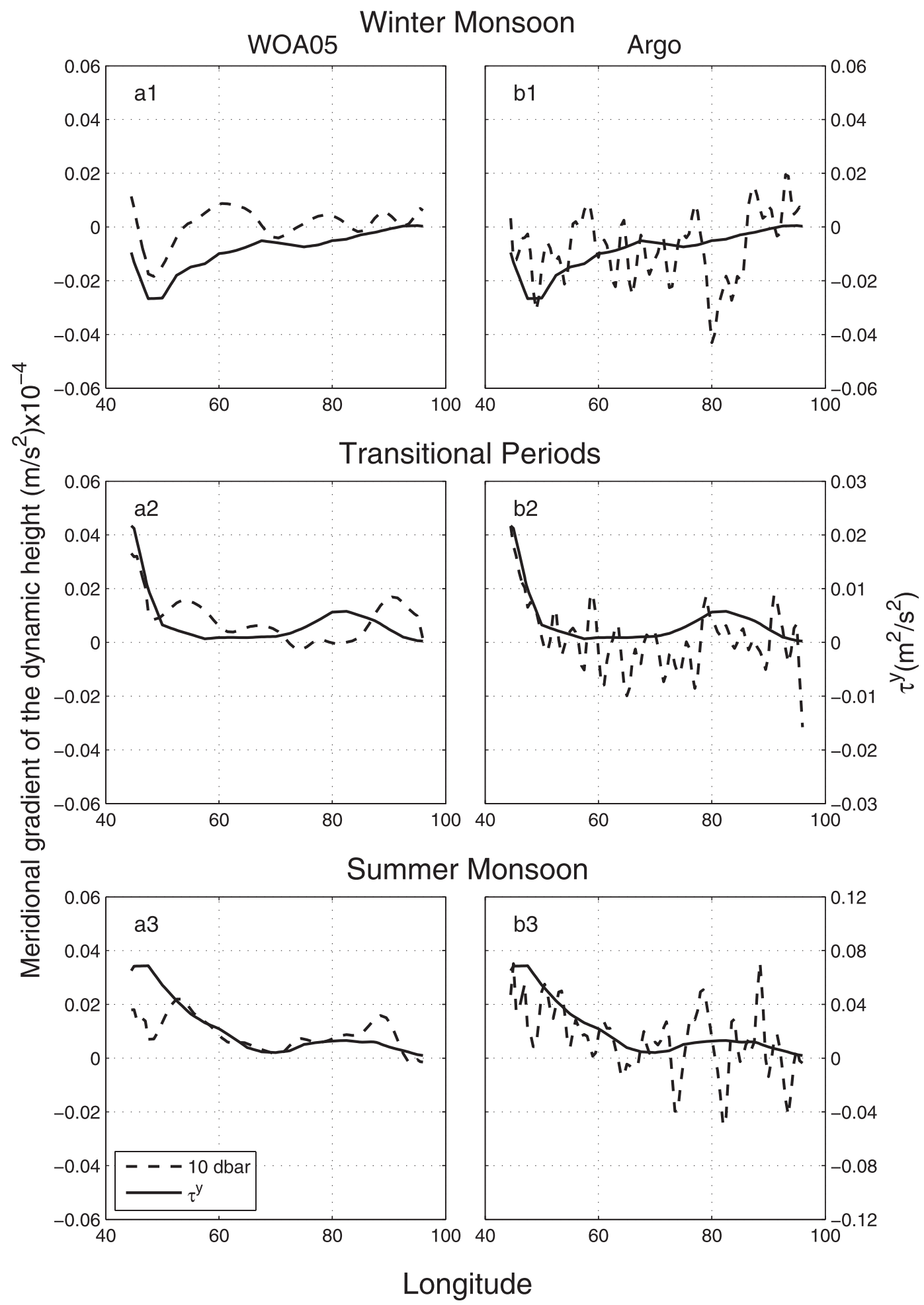

FIG. 5. Meridional wind stress (solid line) and meridional slope of the dynamic height at 10/1000 dbar (dashed line) from (left) WOA05 and (right) objectively analyzed Argo data in each season at the equator of the Indian Ocean as a function of longitude. Note that each season has different y scales for the meridional wind stress. 
WOA05

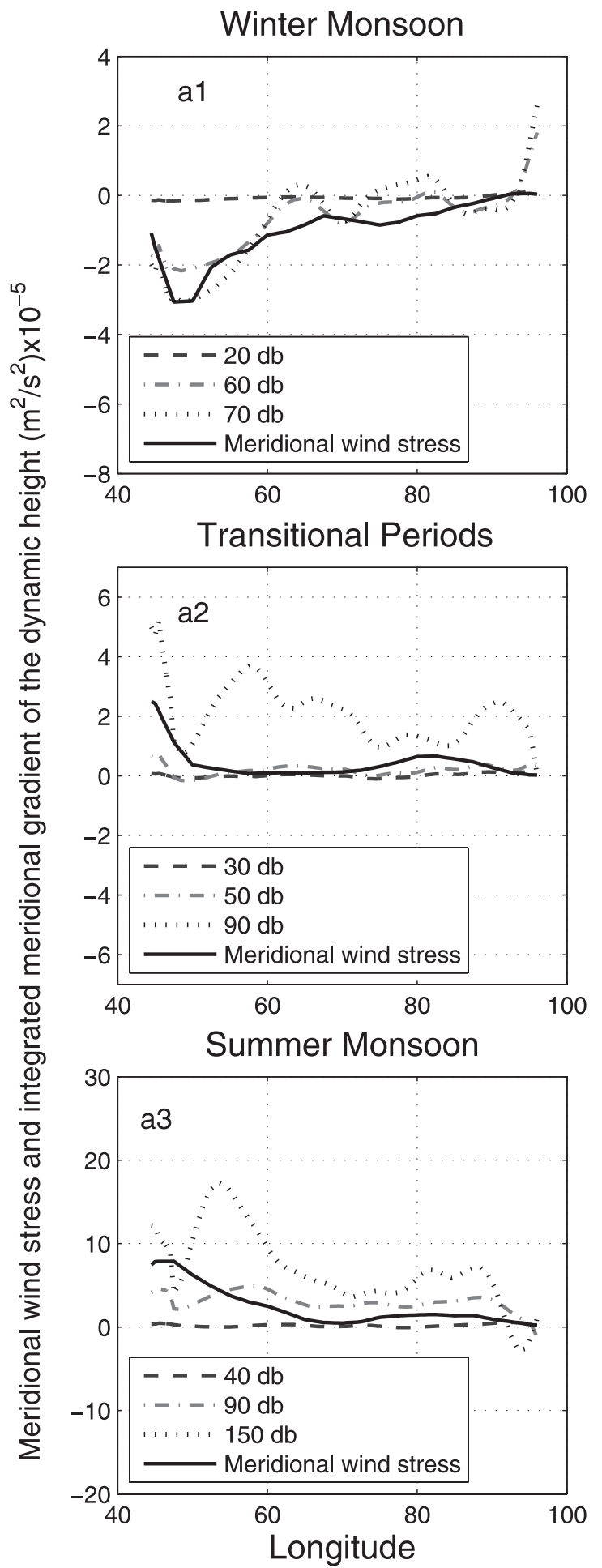

Argo

Winter Monsoon
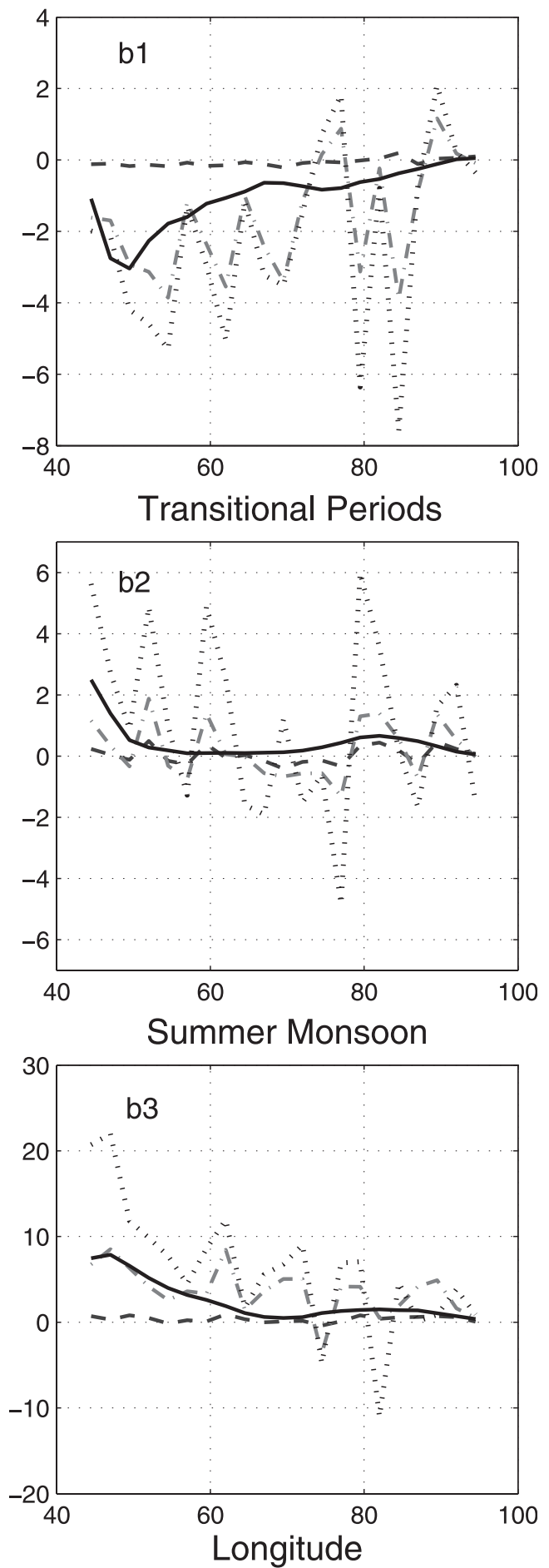

FIG. 6. Meridional wind stress (solid line) and integrated meridional gradient of the dynamic height at different reference pressures (dashed lines) along the equatorial Indian Ocean from (a) WOAO5 and (b) objectively analyzed Argo data. Each season has a different $y$ scale and reference pressures. 


\section{Winter Monsoon}

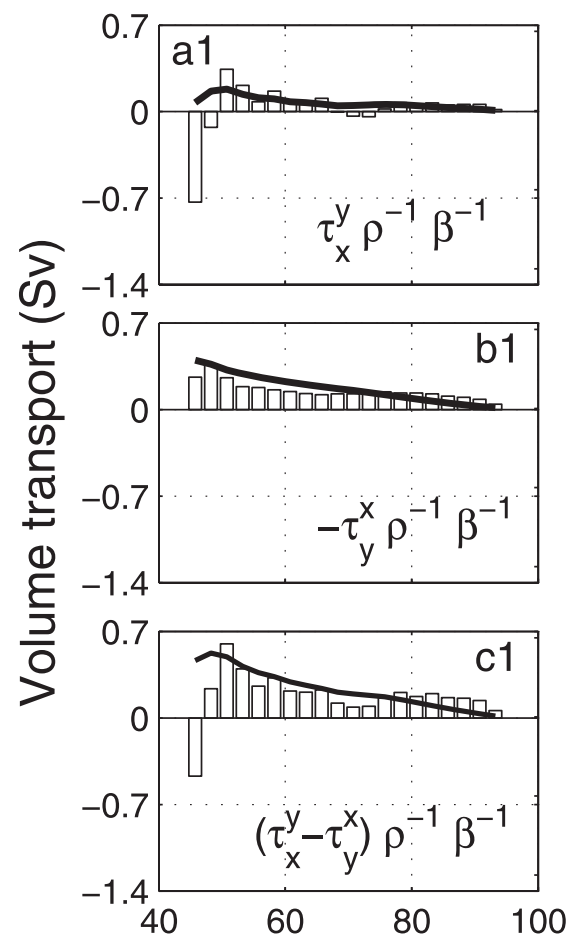

Transitional Periods Summer Monsoon
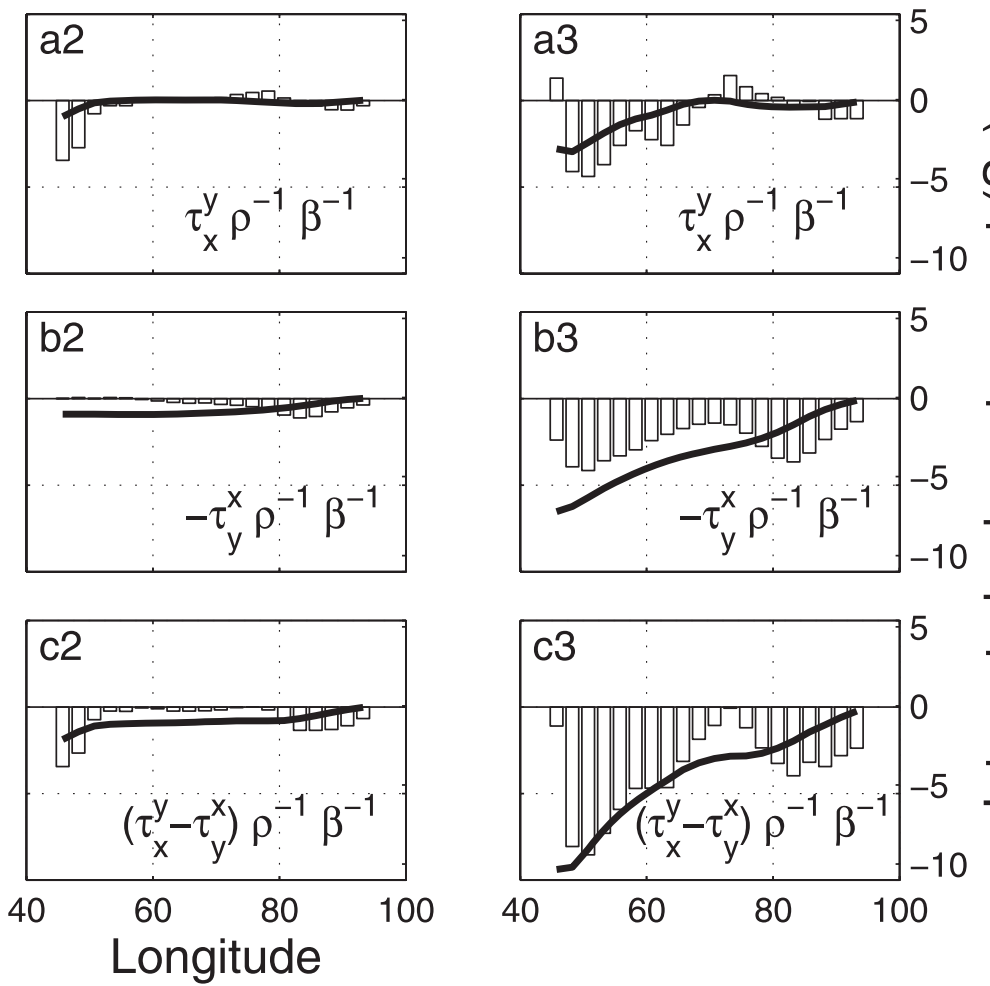

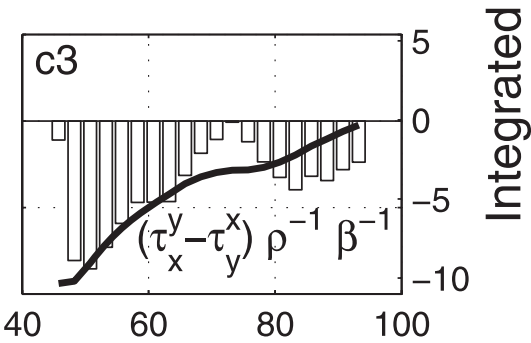

FIG. 7. Zonal distribution (bars, scale left) and accumulated volume transport (from the eastern boundary) (solid line, scale right) of each component of the wind stress curl [(top) $\tau_{x}^{y} \rho^{-1} \beta^{-1}$, (middle) $\tau_{y}^{x} \rho^{-1} \beta^{-1}$, and (bottom) wind stress curl] and total corresponding to the (left) winter monsoon, (middle) transitional periods, and (right) summer monsoon.

The unbalanced zonally integrated transport is calculated from WOAO5 and from the objectively analyzed Argo data using the fact that $\tau_{z}^{y}=P_{y}$. The reference level $-z_{r}$, shown in Fig. 8 is chosen to be the pressure where the volume transport from $\int_{-z_{r}}^{0} P_{x y} d z$ matches that from $\tau_{x}^{y}(z=0)$ at each longitude. Figure 9 shows the unbalanced zonal integrated vertical profile for the frictional term determined from the wind, the vertical profile from the hydrographic data and the total for the winter monsoon, transitional periods, and summer monsoon, for WOA05 (Figs. 9b,c) and Argo data (Figs. 9d,e). The frictional term (Figs. 9a) is assumed to have an exponential decay from the sea surface with an $e$-folding distance of $100 \mathrm{dbar}$ as in Joyce (1988a).

During the winter monsoon and transitional periods, both WOA05 and Argo data show total southward flows in the surface layer (Figs. 9c1,e1,c2,e2) arising from $P_{x y}$ (Figs. 9b1,d1,b2,d2). The transports are higher in the Argo data. In contrast, the total transport in the surface layer (also arising from $P_{x y}$ ) for the summer monsoon is different depending on the hydrographic data used: southward flow for WOA05 (Fig. 9c3) and northward flow for Argo data (Fig. 9e3). A plausible explanation for this result is that the Somali Current is not as strong in the WOA05 data as it is in the Argo data, as will be shown in the next subsection. In each season, the vertical pattern of the total transport from the Argo data consists of a deep flow opposite to the surface transport. In contrast, the total transport from WOA05 mainly consists of alternate currents flowing in opposite directions.

\section{c. Meridional velocities}

The zonal structure of the unbalanced meridional velocities $\tilde{v}$ were obtained using Eq. (2) and an unbalanced volume transport is calculated (Fig. 9). Assuming that higher-order dynamics not considered in the model can be found at the western boundary, the imbalance is added to the western boundary. The imbalance is defined as the negative of the zonal integral of the flow at each depth interval, starting from the secondmost western longitude $\left(45.75^{\circ} \mathrm{E}\right)$ and extending to the eastern boundary $\left(48.25^{\circ} \mathrm{E}-93.25^{\circ} \mathrm{E}\right)$. Then, balanced transports and velocities are obtained. Figure 10 shows the balanced meridional velocities (hereafter meridional velocities) for each season for WOA05 and Argo data 


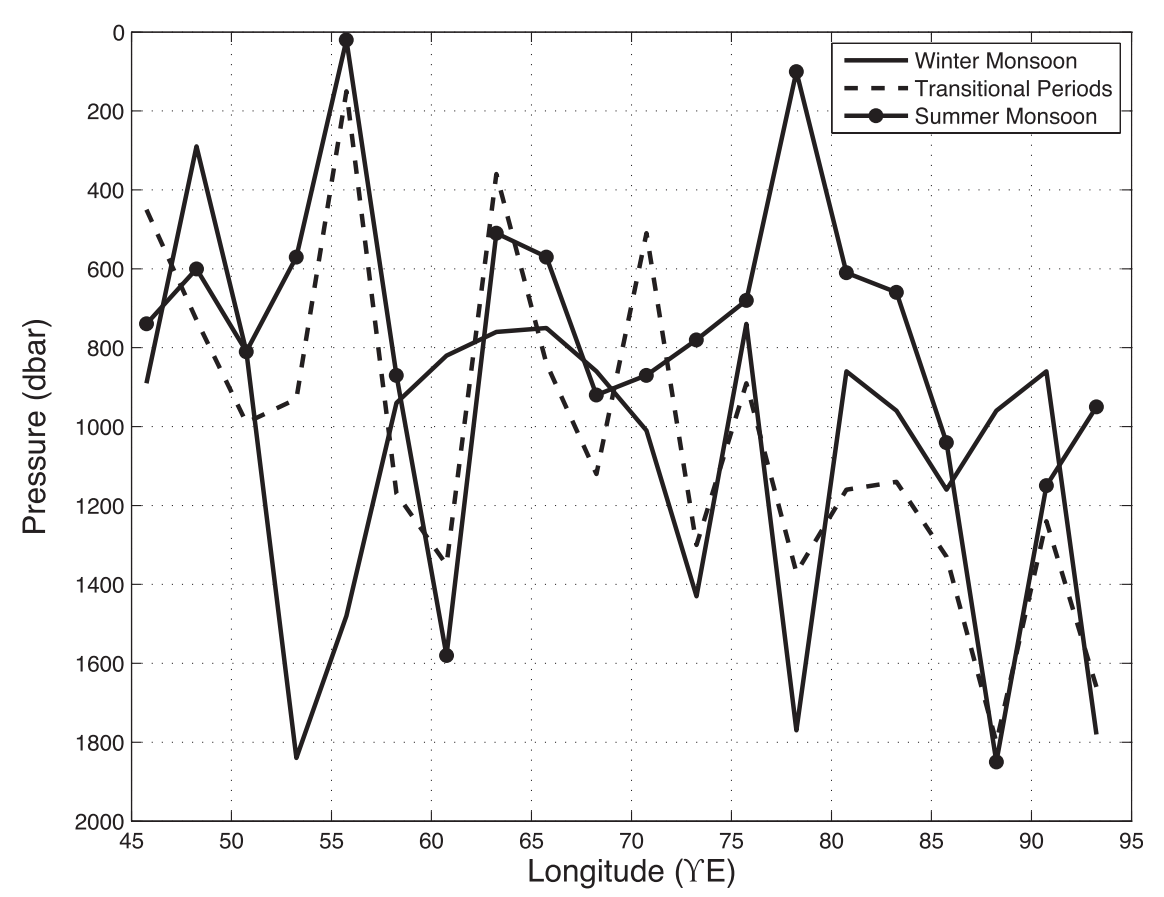

FIG. 8. Reference pressure per longitude and season that satisfies Eq. (1).

once the imbalance is added to the western boundary. This method assumes there is no zonally integrated net flow at each depth in the Indian Ocean: clearly a strong assumption.

The Monte Carlo method from WOA05 standard error of the statistical mean gives a maximum velocity uncertainty of $\sim 5 \mathrm{~cm} \mathrm{~s}^{-1}$ in the Somali Current and in the surface layer. In contrast, the Monte Carlo of Argo bootstrap analysis reveals an uncertainty of $\sim 2-3 \mathrm{~cm} \mathrm{~s}^{-1}$ in the Somali Current and of $\sim 2 \mathrm{~cm} \mathrm{~s}^{-1}$ in the $80^{\circ} \mathrm{E}$ eddy. The remaining Argo surface velocity uncertainties are in the range $1-2 \mathrm{~cm} \mathrm{~s}^{-1}$. In the deep layers ( $>500 \mathrm{dbar}$ ), the range decreases to $0.5-0.9 \mathrm{~cm} \mathrm{~s}^{-1}$ for WOA05 and to $0.3-0.9 \mathrm{~cm} \mathrm{~s}^{-1}$ for Argo. Overall, the uncertainty (standard error of the mean) for the WOA05 climatology is higher than the one for the Argo analyses. The Argo synthetic sections were builtup with more data, and this decreases the standard error of the mean. Thus, all balanced velocities shown in Fig. 10 are significantly different than zero.

At the western boundary, the objectively analyzed Argo data show stronger Somali Current than the WOA05 data. During the winter monsoon WOA05 and Argo data present a southward Somali Current that flows with balanced velocities higher than $20 \pm 9.6 \mathrm{~cm} \mathrm{~s}^{-1}$ and $30 \pm 1.8 \mathrm{~cm} \mathrm{~s}^{-1}$, respectively (Figs. 10a1,b1). In contrast, during the summer monsoon the Somali Current reverses, flowing northward with velocities higher than $30 \pm 8.2 \mathrm{~cm} \mathrm{~s}^{-1}$ in WOA05 and $35 \pm 3.0 \mathrm{~cm} \mathrm{~s}^{-1}$ in Argo
(Figs. 10a3,b3). Leetmaa et al. (1982), using in situ data, documented this reversing flow between the transitional period in April and early May and the summer monsoon during the onset of southerly winds.

The structure of the Somali Current is quite different for each season and data. WOA05 meridional balanced velocities in the winter monsoon show a western boundary current that reaches the $1000 \mathrm{dbar}$ and that can be found west of $50^{\circ} \mathrm{E}$ (Fig. 10a1). Although the Argo Somali Current is also west of $50^{\circ} \mathrm{E}$, it is confined to the upper 200 dbar (Fig. 10b1). Despite this difference the Somali Current in this season is nearest to the coast (Diansky et al. 2006) transporting $-11.5 \pm 1.3 \mathrm{~Sv}$ (with WOA05 data) and $-12.3 \pm 0.3 \mathrm{~Sv}$ (with Argo data).

In the transitional periods there is not a clear western boundary current (Figs. 10a2,b2). It is, apparently, a northward transport of a clockwise eddy, in both cases. If the Somali Current flows in a different direction during each transitional period, then on average, it could be expected that the Somali Current is not present in our transitional periods season composite 'season'.

During the summer monsoon, balanced meridional velocities show that Somali Current spreads farther offshore, being west of $\sim 52^{\circ} \mathrm{E}$ and over the first 200 and 600 dbar in the WOA05 and Argo balanced velocities respectively (Figs. 10a3,b3). Another difference between the balanced velocities is that on the western boundary, Argo data indicate a weak countercurrent that is less than $5 \pm 0.8 \mathrm{~cm} \mathrm{~s}^{-1}$. The western boundary 
WOA05

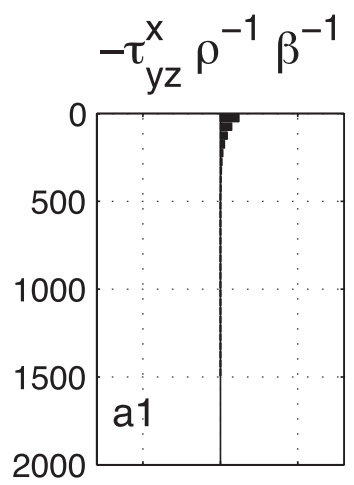

Total transport

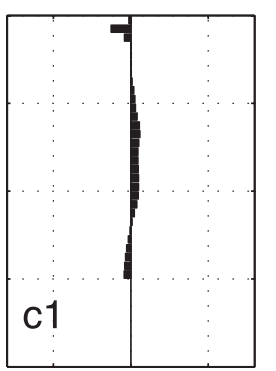

Argo
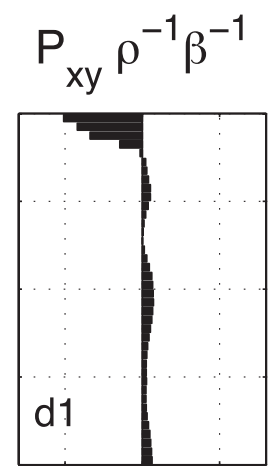

Total transport

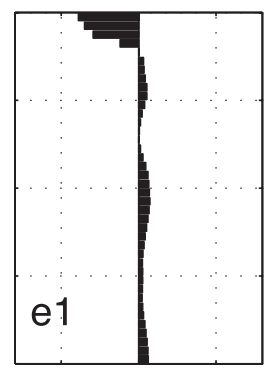

\section{Winter Monsoon Transport (Sv)}
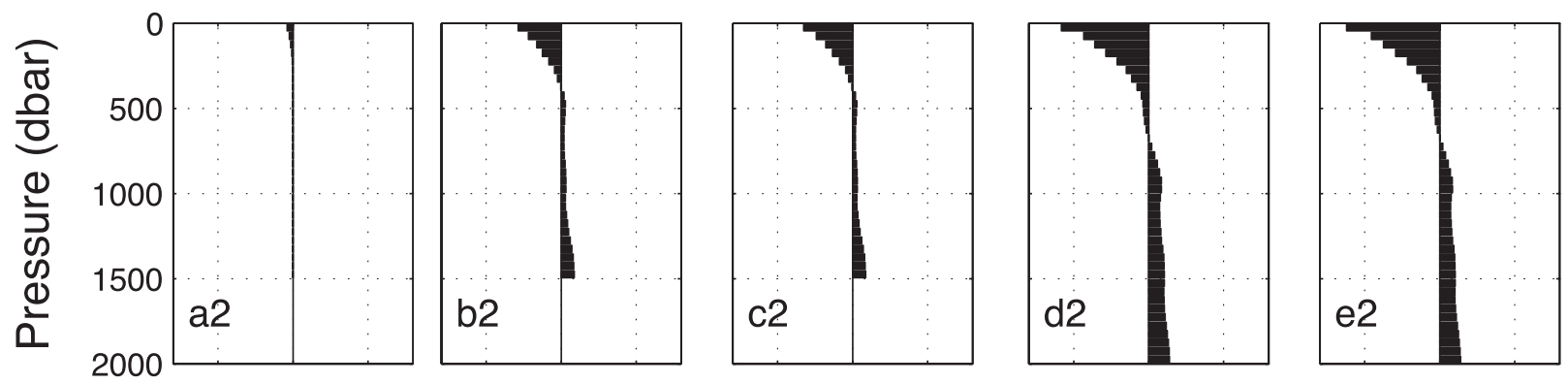

\section{Transitional Periods Transport (Sv)}
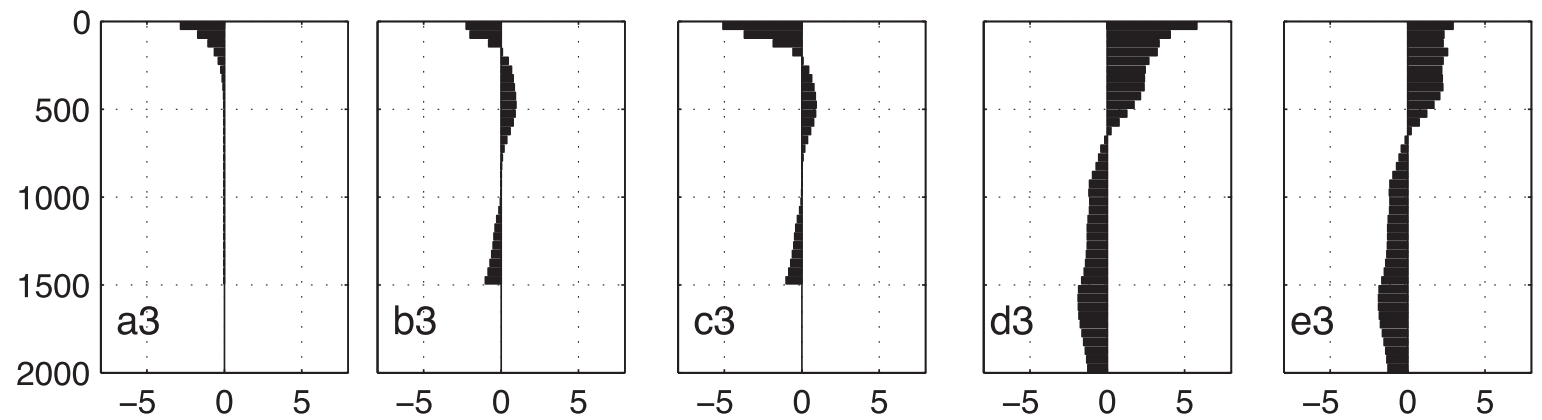

\section{Summer Monsoon Transport (Sv)}

FIG. 9. Unbalanced zonally integrated volume transport (Sv) every 50 dbar for (a) $-\tau_{y z}^{x}$, (b) $P_{x y}$, and (c) total transport from WOA05, and from (d),(e) objectively analyzed Argo data for each season.

current in this season flows northward transporting $16.8 \pm 1.2 \mathrm{~Sv}$ using WOA05 and 19.8 $\pm 0.6 \mathrm{~Sv}$ using Argo. Considering the weak countercurrent at $\sim 400$ dbar, the Argo Somali Current transport will decrease to $14.5 \pm 0.7 \mathrm{~Sv}$.

\section{d. Heat transport}

We have used our balanced velocities to estimate the heat transported by the Indian Ocean across the equator. In this estimation, we have not taken into account the heat transport deeper than $2000 \mathrm{~m}$.

Table 1 shows the heat transported by the Somali Current for the WOA05 and Argo data at each season and the annual. The annual heat transport has been calculated as the mean of the heat transport for each season, and its error has been obtained using the law of propagation of uncertainty. Annual heat transport presents opposite directions in the Somali Current and 

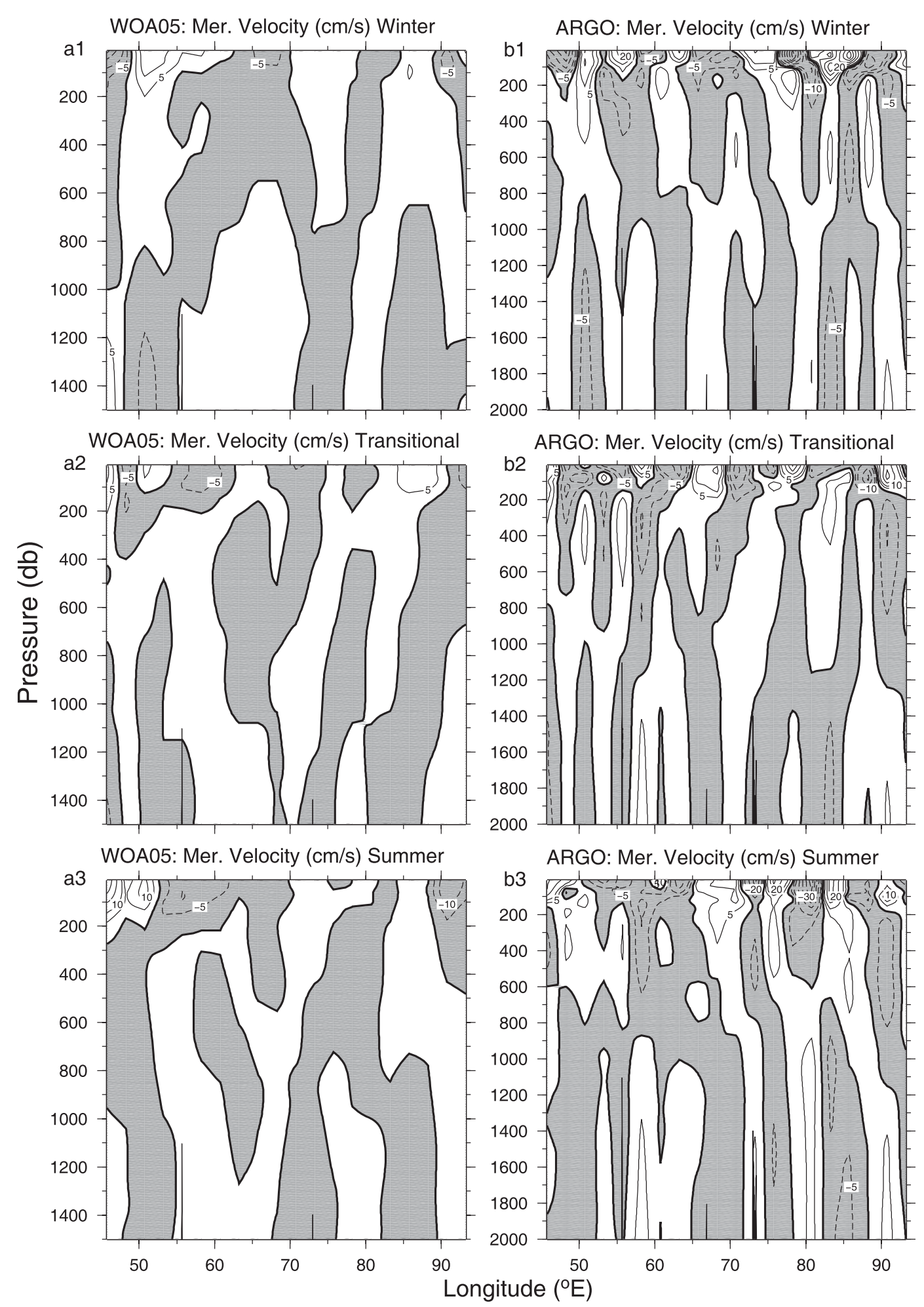

FIG. 10. Vertical sections of balanced meridional velocity $\left(\mathrm{cm} \mathrm{s}^{-1}\right)$ at the equatorial Indian Ocean for (a) WOA05 and (b) objectively analyzed Argo data for each season. Negative velocities are shaded. The isoline interval is 5 to $10 \mathrm{~cm} \mathrm{~s}^{-1}$ and $10 \mathrm{~cm} \mathrm{~s}^{-1}$ thereafter. 
TABLE 1. Heat transport (PW) per season and annual (obtained as the mean of the three seasons) for WOA05 and Argo data from balanced volume transport to 1500 and 2000 dbar, respectively. The first row shows the heat transport due to the Somali Current, where the imbalance has been included, while the second row is the ocean interior contribution. The corresponding months for each period are shown after the period name.

\begin{tabular}{|c|c|c|c|c|c|c|c|c|}
\hline & \multicolumn{2}{|c|}{$\begin{array}{c}\text { Winter monsoon } \\
{[\text { December-March (DJFM)] }}\end{array}$} & \multicolumn{2}{|c|}{$\begin{array}{c}\text { Transitional periods } \\
{[\text { April-November (AMON)] }}\end{array}$} & \multicolumn{2}{|c|}{$\begin{array}{c}\text { Summer monsoon } \\
\text { [June-September (JJAS)] }\end{array}$} & \multicolumn{2}{|c|}{ Annual } \\
\hline & WOA05 & Argo & WOA05 & Argo & WOA05 & Argo & WOA05 & Argo \\
\hline Somali Current & $-0.94 \pm 0.13$ & $-1.24 \pm 0.03$ & - & - & $+1.60 \pm 0.11$ & $+1.48 \pm 0.03$ & $+0.22 \pm 0.06$ & $+0.08 \pm 0.01$ \\
\hline Ocean interior & $+0.92 \pm 0.22$ & $+1.23 \pm 0.06$ & $+0.02 \pm 0.08$ & $+0.01 \pm 0.13$ & $-1.73 \pm 0.21$ & $-1.58 \pm 0.11$ & $-0.26 \pm 0.13$ & $-0.11 \pm 0.06$ \\
\hline
\end{tabular}

the ocean interior. According to the volume transports in the transitional periods no calculations were made for the Somali Current, and the whole area is considered as ocean interior. The transitional periods do not have a transport significantly different from zero. For both data the Somali Current and the ocean interior heat transports are higher in the summer monsoon than in winter monsoon. In the winter monsoon the Somali Current carries more heat than the ocean interior in both datasets while for the summer monsoon the ocean interior seems to have higher heat transport than the Somali Current. Heat transports in Table 1 were obtained based on the assumption that the zonally integrated flow across the equator is zero at all depths and that there is no heat transport below our deepest depths (1500 dbar for WOA05 and 2000 dbar for Argo).

\section{Discussion}

A steady-state model proposed by Joyce (1988a) has been evaluated in the equatorial Indian Ocean using NCEP wind stress, WOA05, and objectively analyzed Argo data. The seasonal behavior of the monsoons that drive the ocean circulation in the Indian Ocean leads us to consider separately the winter and summer monsoons and the transitional periods. This model has been used before to study seasonal data in the Atlantic Ocean (Joyce 1988b).

In each season, the wind and the dynamic height present a dynamical balance. As expected, Argo data clearly show a stronger eddy field than WOA05 data. A high mesoscale signal in the meridional component of the velocity in the equatorial Indian Ocean at $70.2^{\circ}$ and $80.5^{\circ} \mathrm{E}$ is clearly seen from current meters and ADCP data shown in McPhaden (1982) and Reppin et al. (1999), respectively. Meridional velocity reversals from positive to negative are shown in these studies with a much shorter time scale than the zonal velocity. This high mesoscale signal is present in our Argo meridional velocities.

A reversal of the Somali Current between each monsoon has been found. This behavior has been widely reported as seen in Duing et al. (1980), Leetmaa et al. (1980), Luyten et al. (1980), Quadfasel and Schott (1982), Leetmaa et al. (1982), Schott (1986), Schott et al. (1990), and Donguy and Meyers (1995). The balanced meridional velocities in the Somali Current are higher during the summer monsoon than the winter monsoon in both datasets, previously reported by Schott et al. (1990). In the winter monsoon the Somali Current is nearer to the coast (Diansky et al. 2006). Argo winter monsoon Somali Current structure fits better with previous studies. Those studies suggest that the Somali Current is shallower than 300 dbar (Schott et al. 1990; Schott and McCreary 2001; Swallow et al. 1991). The deepening of Argo summer monsoon Somali Current has been observed also in Schott et al. (1990). In contrast to what Schott et al. (1990) found, our results do not show any serious countercurrent, some reversal can be seen, but its velocity is always below the absolute $7 \mathrm{~cm} \mathrm{~s}^{-1}$.

The balanced volume transports for the Somali Current in the winter monsoon are $-11.5 \pm 1.3 \mathrm{~Sv}$ (WOA05) and $-12.3 \pm 0.3 \mathrm{~Sv}$ (Argo), this transport agrees with the 11-12 Sv flowing southward that Donguy and Meyers (1995) found at $10^{\circ} \mathrm{N}$ in the upper 400 dbar in the months of January and February. In contrast, Schott et al. (1990) found -1.1 Sv in the winter monsoon. This discrepancy is explained by the different offshore measurements of the Somali Current, our first longitude is $\sim 44.5^{\circ} \mathrm{E}$, while Schott et al. (1990) mooring array was farther west, between the coast and $\sim 44.5^{\circ} \mathrm{E}$, obtaining in consequence data that reaches shallower depths.

The Somali Current balanced volume transport in the summer monsoon is of $16.8 \pm 1.2 \mathrm{~Sv}$ and $19.8 \pm 0.6 \mathrm{~Sv}$ in WOA05 and Argo, respectively. This results are close to the previously published results for this season: $21.1 \mathrm{~Sv}$ (Schott et al. 1990), $19.8 \pm 4.8 \mathrm{~Sv}$ (Swallow et al. 1991), and 21-24 Sv (Donguy and Meyers 1995).

In contrast, a lack of in situ studies on the eastern boundary exists at the equator. In Quadfasel and Cresswell (1992) is established that the eastern boundary current flows southeastward throughout the year. 

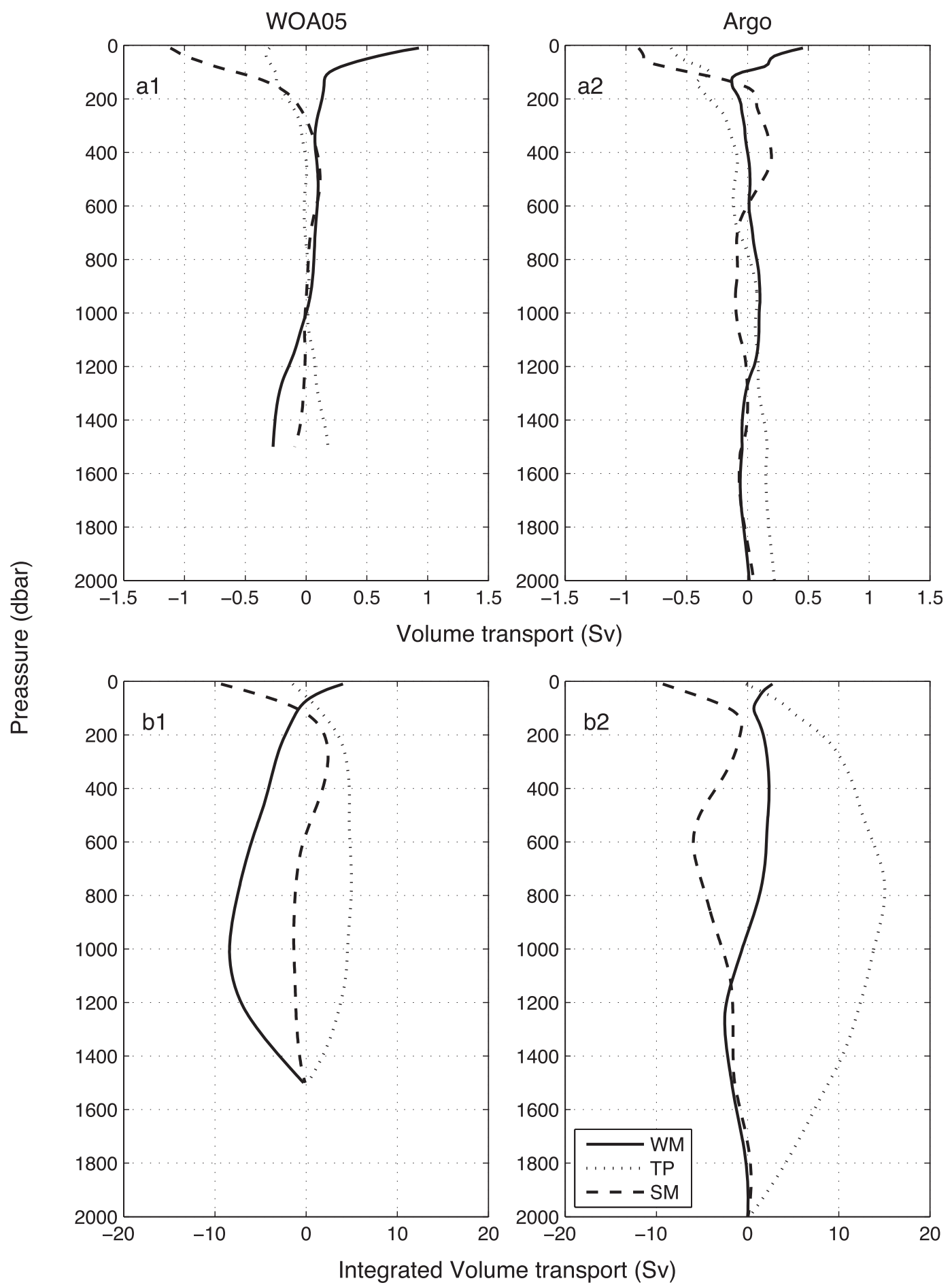

FIG. 11. Vertical structure of the volume transport for the ocean interior for (a1) WOA05 and (a2) Argo at each season, and the integrated, from the bottom, volume transport for (b1) WOA05 and (b2) Argo at each season.

This is year-round character is also described in Sprintall et al. (2010) farther south. Eastern boundary currents are difficult to discern as they carry a small transport and their low signal is mixed with mesoscale eddies
(Sprintall et al. 1999; Hernández-Guerra et al. 2005). This is the case for Argo data where a high mesoscale activity is observed making the end boundary of the eastern current hardly to distinguish in the vertical 

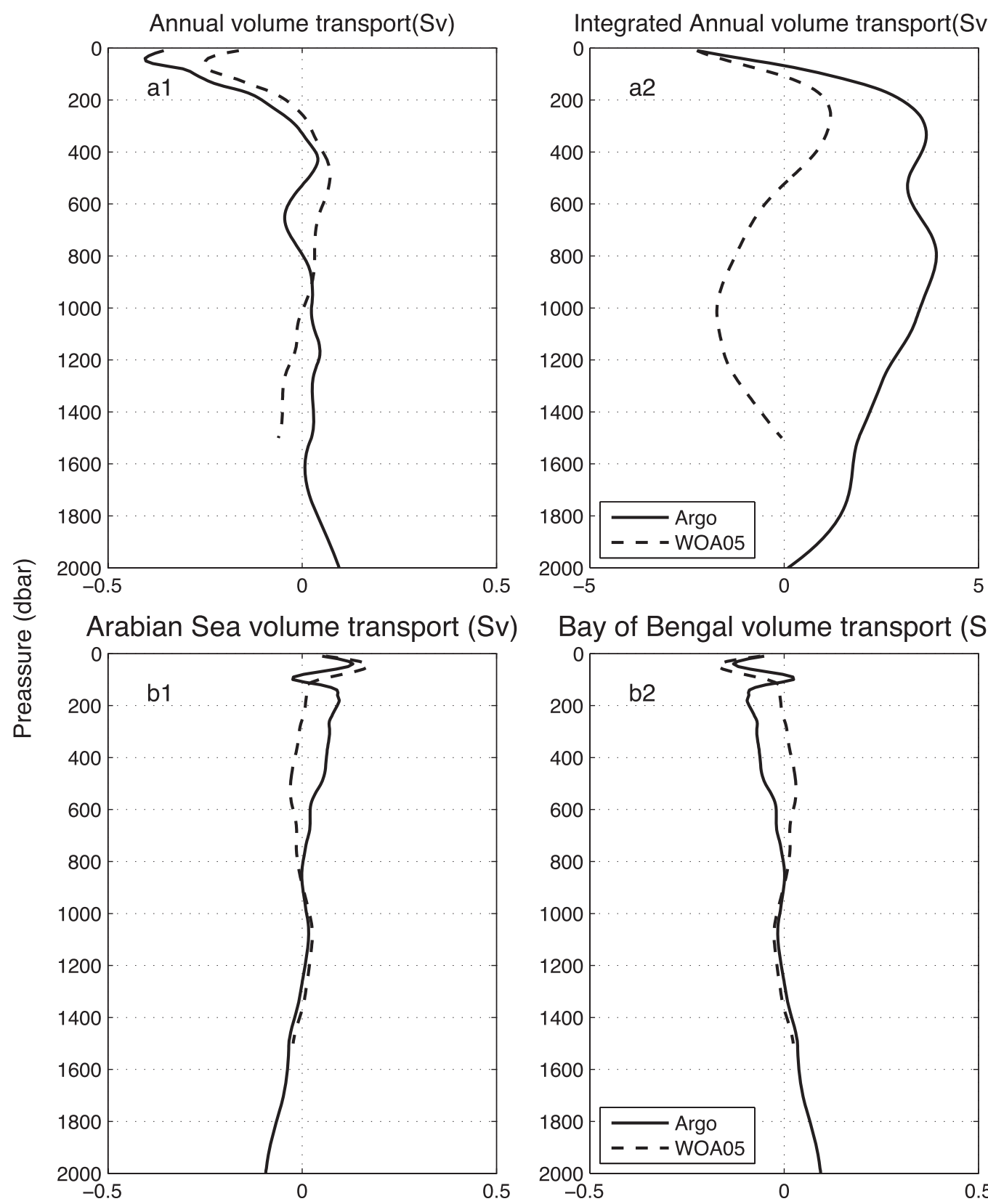

Bay of Bengal volume transport (Sv)

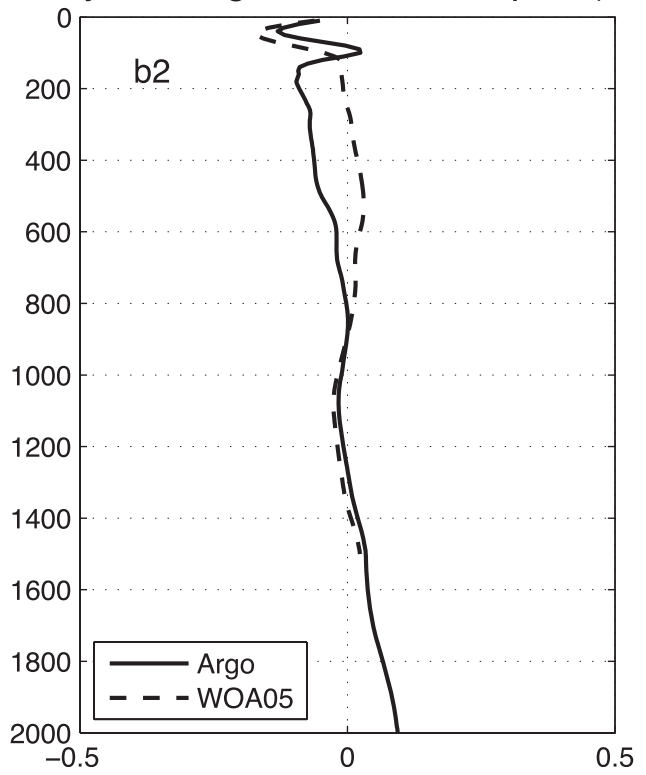

FIG. 12. Vertical structure of the (a1) annual volume transport for each dataset and (a2) the integrated, from the bottom, annual volume transport for each dataset. (bottom) (b1) The annual volume transport in the Arabian Sea for each dataset and (b2) the annual volume transport for the Bay of Bengal. WOA05 is shown with solid lines and Argo with dashed lines.

section of meridional velocity. WOA05 data show a southeastward eastern boundary current in all seasons as previously reported. In the winter monsoon and transitional periods the current carries respectively, $-1.5 \pm$ $0.8 \mathrm{~Sv}$ and $-6.1 \pm 0.8 \mathrm{~Sv}$, in the first $700 \mathrm{dbar}$ from $88.25^{\circ} \mathrm{E}$ to the eastern coast. In the summer monsoon the eastern boundary current transports $-10.7 \pm 0.8 \mathrm{~Sv}$ in the upper 500 dbar. Fieux et al. (1996), Meyers (1996), and Sprintall et al. (2010) estimated a maximum transport in the summer monsoon near Java.

In Fig. 11a, the vertical structure of the interior ocean for each season is shown for WOA05 (Fig. 11a1) and Argo (Fig. 11a2). In both datasets a reversal of the surface flow between monsoons is observable. In the transitional periods positive volume transports are found in the upper $\sim 800 \mathrm{dbar}$ and negative volume transports 
TABLE 2. Volume transport (Sv) for each component of the unbalanced wind stress corresponding to the Somali Current and Ocean Interior per season and the annual mean volume transport. Here, $\tau_{x}^{y},-\tau_{y}^{x}$ and $\tau_{x}^{y}-\tau_{y}^{x}$ are divided by $\rho_{0} \beta$ as in Eq. (2).

\begin{tabular}{|c|c|c|c|c|c|c|c|c|c|c|c|c|}
\hline & \multicolumn{3}{|c|}{$\begin{array}{l}\text { Winter monsoon } \\
(\mathrm{DJFM})\end{array}$} & \multicolumn{3}{|c|}{$\begin{array}{l}\text { Transitional periods } \\
\text { (AMON) }\end{array}$} & \multicolumn{3}{|c|}{$\begin{array}{l}\text { Summer monsoon } \\
\text { (JJAS) }\end{array}$} & \multicolumn{3}{|c|}{ Annual } \\
\hline & $\tau_{x}^{y}$ & $-\tau_{y}^{x}$ & $\tau_{x}^{y}-\tau_{y}^{x}$ & $\tau_{x}^{y}$ & $-\tau_{y}^{x}$ & $\tau_{x}^{y}-\tau_{y}^{x}$ & $\tau_{x}^{y}$ & $-\tau_{y}^{x}$ & $\tau_{x}^{y}-\tau_{y}^{x}$ & $\tau_{x}^{y}$ & $-\tau_{y}^{x}$ & $\tau_{x}^{y}-\tau_{y}^{x}$ \\
\hline Somal & -0.73 & 0.26 & -0.47 & -0.48 & 0.00 & -0.48 & 0.18 & 0.34 & 0.52 & -0.34 & 0.20 & -0.14 \\
\hline Ocean interior $(\mathrm{Sv})$ & 1.23 & 2.79 & 4.03 & -0.59 & -1.06 & -1.65 & -3.30 & -6.88 & -10.18 & -0.89 & -1.72 & -2.61 \\
\hline
\end{tabular}

below them. Integrating these transports from our bottom (1500 dbar for WOA05 and 2000 dbar for Argo) to the surface (Figs. 11b1,b2) a closed cell appears in both the transitional periods and in the WOA05 winter monsoon. Those cells present a maximum volume transport of $5.0 \pm 0.6 \mathrm{~Sv}$ (at $750 \mathrm{dbar}$ ), $15.0 \pm 0.5 \mathrm{~Sv}$ (at $780 \mathrm{dbar}$ ) and $-8.4 \pm 0.5 \mathrm{~Sv}$ (at $1010 \mathrm{dbar}$ ) for the WOA05 and Argo transitional periods and for the WOA05 winter monsoon, respectively. Our results show that in the WOA05 transitional composite season, where no Somali Current is obtained, the meridional overturning circulation cell is much shallower than the one observed for the WOA05 winter monsoon. Although we are not considering the western boundary in those calculations because we have assumed balanced transports, it seems that during the monsoons, the meridional overturning circulation might be much deeper than in the transitional periods.

The ocean interior annual volume transport (obtained as the mean of the three seasons) and the integrated annual volume transport is showed in Fig. 12a. In this figure we can see that when the monsoons are added to the integrated volume transport calculations WOA05 presents two overturning cells, one shallow $260 \mathrm{dbar}$ $(1.2 \pm 1.6 \mathrm{~Sv})$, and one deep $1020 \mathrm{dbar}(-1.7 \pm 0.9 \mathrm{~Sv})$ while Argo only show one at $800 \mathrm{dbar}(3.7 \pm 0.9 \mathrm{~Sv})$. McDonagh et al. (2008) states that the estimated strength of the meridional overturning circulation at $32^{\circ} \mathrm{S}$ has varied from 2 to $27 \mathrm{~Sv}$ in the estimated depths of 1400 and $3700 \mathrm{~m}$. Our results agree with the meridional overturning circulation transports of $3.5 \mathrm{~Sv}$ obtained by $\mathrm{Fu}(1986)$ and $8.8 \pm 4 \mathrm{~Sv}$ by Sultan et al. (2007) from inverse models carried out in the southern Indian Ocean. In contrast, our results are smaller than those found by Ganachaud et al. (2000) and Robbins and Toole (1997) at $32^{\circ} \mathrm{S}$.

We have computed our annual vertical structure of volume transport for the Arabian Sea $\left(48.25^{\circ}-78^{\circ} \mathrm{E}\right)$ and for the Bay of Bengal $\left(78^{\circ}-93.25^{\circ} \mathrm{E}\right)$ (Fig. 12b). Those structures look quite similar to the upper depths of ones obtained by Shi et al. (2002). In the Arabian Sea, Shi et al. (2002) found a subsurface positive transport maximum that decreases to zero at $\sim 800-900 \mathrm{~m}$. Below that depth the transport turns into negative until the $\sim 2000 \mathrm{~m}$. The subsurface maximum can be found in both WOA05 and Argo, but while Argo transport below it resembles that of Shi et al. (2002), WOA05 is positive from $\sim 200$ to $\sim 800$ dbar (Fig. 12b1). Shi et al. (2002) Bay of Bengal profile is negative over the $\sim 600 \mathrm{~m}$ with a peak at $\sim 100 \mathrm{~m}$. Below the $600 \mathrm{~m}$ the transport becomes positive until the $\sim 2800 \mathrm{~m}$. Although both WOA05 and Argo shows the same surface peak, Argo volume transport profile for the Bay of Bengal presents a better match with the one of Shi et al. (2002) (Fig. 12b2).

To the extent that our results in volume transport agree with previous independent studies, we can further estimate the heat transport across the equatorial Indian Ocean to 2000 dbars (1500 dbar in the case of WOA05) using the balanced transport. As demonstrated by Warren (1999) heat transport can only be unambiguously given in PW if the mass is balanced. This is not our case, because we have only mass balanced to 1500 or $2000 \mathrm{dbar}$ depending on the data used. Anyway, we have kept the PW as unit of heat flux. The seasonal heat transport of the ocean interior resembles the cross-equatorial heat transport presented by Loschnigg and Webster (2000) from an Indian Ocean model driven with daily wind stress. The ocean interior annual heat transports (obtained as the mean of the three seasons) are $-0.26 \pm$ $0.13 \mathrm{PW}($ WOA05) and $-0.11 \pm 0.06 \mathrm{PW}$ (Argo) to the south. Several authors have estimated different mean annual heat transports. Hastenrath (1982), Hsiung (1985), and Hastenrath and Greischar (1993) used atmospheric flux determinations to estimate a southward heat transport at the equatorial Indian Ocean in the range -0.4 to $-0.8 \mathrm{PW}$. From models, Wacongne and Pacanowski (1996) and Garternicht and Schott (1997) have estimated annual heat transports of between -0.1 and $-0.2 \mathrm{PW}$ to the south. If we consider that the volume transport below $2000 \mathrm{dbar}$ is to the north in the Indian Ocean as seen by Ganachaud and Wunsch (2000), our estimate of heat transport would decrease.

Godfrey et al. (2001) and Godfrey et al. (2007) have also estimated the meridional volume and heat flux in the equatorial Indian Ocean. In these studies, they have neglected the meridional component of the wind stress. 
TABLE 3. Heat flux (PW) for the Somali Current and Ocean Interior as obtained using data once balanced from Table 2 and temperature data from Argo to 2000 dbar.

\begin{tabular}{|c|c|c|c|c|c|c|c|c|}
\hline & \multicolumn{2}{|c|}{$\begin{array}{l}\text { Winter monsoon } \\
\text { (DJFM) }\end{array}$} & \multicolumn{2}{|c|}{$\begin{array}{c}\text { Transitional periods } \\
\text { (AMON) }\end{array}$} & \multicolumn{2}{|c|}{$\begin{array}{c}\text { Summer monsoon } \\
\text { (JJAS) }\end{array}$} & \multicolumn{2}{|c|}{ Annual } \\
\hline & $\begin{array}{l}\text { Present } \\
\text { Work }\end{array}$ & $\begin{array}{c}\text { Godfrey } \\
\text { et al. (2001) }\end{array}$ & $\begin{array}{l}\text { Present } \\
\text { Work }\end{array}$ & $\begin{array}{c}\text { Godfrey } \\
\text { et al. (2001) }\end{array}$ & $\begin{array}{l}\text { Present } \\
\text { Work }\end{array}$ & $\begin{array}{c}\text { Godfrey } \\
\text { et al. (2001) }\end{array}$ & $\begin{array}{l}\text { Present } \\
\text { Work }\end{array}$ & $\begin{array}{c}\text { Godfrey } \\
\text { et al. (2001) }\end{array}$ \\
\hline Somali Current (PW) & $-1.24 \pm 0.03$ & -0.20 & - & - & $+1.48 \pm 0.03$ & +0.46 & $+0.08 \pm 0.01$ & +0.09 \\
\hline Ocean interior (PW) & $+1.23 \pm 0.06$ & +0.20 & $+0.01 \pm 0.13$ & -0.00 & $-1.58 \pm 0.11$ & -0.49 & $-0.11 \pm 0.06$ & -0.10 \\
\hline
\end{tabular}

We have carried out an analysis of the volume transport of each component of Eq. (2) to assess their relative weight as shown in Table 2. The transport associated with the component $\tau_{x}^{y}$, ignored by Godfrey et al. (2001), is about half of the transport associated with $\tau_{y}^{x}$ for the ocean interior. We have further analyzed the difference between our results and Godfrey et al. (2001) results considering heat flux. As seen in Table 3, the Somali Current and the ocean interior heat fluxes have the same direction using Joyce (1988a) and Godfrey et al. (2001) models. However, our results show a higher heat transport in each season resulting in a stronger seasonal variation. The annual heat transport from both models presents similar heat transport for the Somali Current and for the ocean interior.

To conclude, the model can be used with seasonal data to study meridional velocities in the equatorial Indian Ocean monsoon regime. Model results fit with in situ measurements made around the region, although Argo data results are quite more realistic than WOA05 data results.

Acknowledgments. The Argo data used here were collected and made freely available by the International Argo Project and the national programs that contribute to it (available online at http://www.argo.net). Argo is a pilot program of the Global Ocean Observing System. The wind speed data were obtained from the National Centers for Environmental Prediction (NCEP) Reanalysis Project (http://www.cpc.ncep.noaa.gov//products/ wesley/reanalysis.html) from the National Oceanic and Atmospheric Administration (NOAA). This study has been partly funded by the MOC Project (CTM 200806438) and the Spanish contribution to the Argo network (AC2009 ACI2009-0998), financed by the Spanish Government and Feder. We thank Eugenio Fraile-Nuez and Verónica Benítez-Barrios for their helpful comments on the manuscript. The first author will like to thank the Agencia Canaria de Investigación, Innovación y Sociedad de la Información (ACIISI) grant program of Apoyo al Personal Investigador en Formación and to thank the Woods Hole Oceanographic Institution
(WHOI) for the opportunity to visit for an extended period of 3 months in 2011 as a guest student.

\section{APPENDIX}

\section{Wind Products}

As the model mainly depends on wind stress, the most plausible source of systematic errors comes from the chosen wind stress data product. To explore this, QS winds collected from satellite were used too. NCEP meridional velocities in the Somali Current region were $0.2-1.8 \mathrm{~m} \mathrm{~s}^{-1}$ times bigger than the QS winds for the winter monsoon and transitional periods respectively. In contrast for summer monsoon, in the same region, NCEP winds were $0.2 \mathrm{~m} \mathrm{~s}^{-1}$ weaker than QS winds. Goswami and Sengupta (2003) found a similar behavior, 1-1.5 $\mathrm{m} \mathrm{s}^{-1}$ stronger NCEP than QS during the winter monsoon and 1-2 $\mathrm{m} \mathrm{s}^{-1}$ weaker NCEP than QS during the summer monsoon. Differences between our values and Goswami and Sengupta (2003)'s are consequences of the different period used as they only uses years 2000/01. The differences between QS and NCEP zonal mean of $U$ and $V$ agrees with Goswami and Sengupta (2003) in that the whole equatorial area presents weaker NCEP than QS in the winter $\left(\bar{U}_{\mathrm{QS}-\mathrm{NCEP}}=\right.$ $\left.1.97 \mathrm{~m} \mathrm{~s}^{-1}, \bar{V}_{\mathrm{QS}-\mathrm{NCEP}}=0.06 \mathrm{~m} \mathrm{~s}^{-1}\right)$ and summer monsoon $\left(\bar{U}_{\mathrm{QS}-\mathrm{NCEP}}=0.35 \mathrm{~m} \mathrm{~s}^{-1}, \bar{V}_{\mathrm{QS}-\mathrm{NCEP}}=0.02 \mathrm{~m} \mathrm{~s}^{-1}\right)$. These differences are translated afterward into the following accumulated wind stress curl volume transport for the NCEP (QS) 3.5 Sv (38.9 Sv), $-2.1 \mathrm{~Sv}(-12.8 \mathrm{~Sv})$, and $-10.3 \mathrm{~Sv}(-38.8 \mathrm{~Sv})$ for the winter monsoon, transitional periods, and summer monsoon, respectively. NCEP and QuikScat volume transports of the wind stress curl present similar behavior: northward flow during the winter monsoon, negative during the transitional periods and summer monsoon, with the volume transport in the transitional periods being lower than in the monsoons. Different results using various wind data products have been previously documented by Schott and McCreary (2001). Higher estimates of Ekman transport from satellite data were also obtained by 
Hernández-Guerra et al. (2010) when compared with NCEP data and results from an inverse model. Goswami and Sengupta (2003) attributes the differences to the precipitation analysis used in each database because Chiang et al. (2001) establishes that winds in the equatorial Indian Ocean are driven primarily by the elevated heating associated with tropical rainfall.

\section{REFERENCES}

Argo Data Management Team, 2002: Argo Data Management Handbook. GODAE, 32 pp.

Barnett, T., 1983: Interaction of the monsoon and Pacific trade wind system at interannual time scales. Part I: The equatorial zone. Mon. Wea. Rev., 111, 756-773.

Chiang, J., S. Zebiak, and M. Cane, 2001: Relative roles of elevated heating and surface temperature gradients in driving anomalous surface winds over tropical oceans. J. Atmos. Sci., 58, 1371-1394.

Diansky, N., V. Zalesny, S. Moshonkin, and A. Rusakov, 2006: High resolution modeling of the monsoon circulation in the Indian Ocean. Oceanology, 46, 608-628.

Donguy, J., and G. Meyers, 1995: Observations of geostrophic transport variability in the western tropical Indian Ocean. Deep-Sea Res. I, 42, 1007-1028.

Duing, W., R. Molinari, and J. Swallow, 1980: Somali current: Evolution of surface flow. Science, 209, 588-590.

Efron, B., and R. Tibshirani, 1993: An Introduction to the Bootstrap. Monographs on Statistics and Applied Probability, Vol. 57, Chapman \& Hall/CRC, 456 pp.

Fieux, M., R. Molcard, and A. Ilahude, 1996: Geostrophic transport of the Pacific-Indian Oceans Throughflow. J. Geophys. Res., 101 (C5), 12 421-12 432.

Fraile-Nuez, E., and A. Hernández-Guerra, 2006: Wind-driven circulation for the eastern North Atlantic Subtropical Gyre from Argo data. Geophys. Res. Lett., 33, L03601, doi:10.1029/ 2005GL025122.

Fu, L., 1986: Mass, heat and freshwater fluxes in the South Indian Ocean. J. Phys. Oceanogr., 16, 1683-1693.

Ganachaud, A., and C. Wunsch, 2000: Improved estimates of global ocean circulation, heat transport and mixing from hydrographic data. Nature, 408, 453-457.

,-- J. Marotzke, and J. Toole, 2000: Meridional overtunning and large-scale circulation of the Indian Ocean. J. Geophys. Res., 105, 26 117-26134.

Garternicht, U., and F. Schott, 1997: Heat fluxes of the Indian Ocean from a global eddy-resolving model. J. Geophys. Res., 102 (C9), 21 147-21 159.

Godfrey, J., G. C. Johnson, M. McPhaden, G. Reverdin, and S. E. Wijffels, 2001: The tropical ocean circulation. Int. Geophys., 77, 215-246.

— R. Hu, A. Schiller, and R. Fiedler, 2007: Explorations of the annual mean heat budget of the tropical indian ocean. Part I: Studies with an idealized model. J. Climate, 20, 3210-3228.

Gomis, D., and M. Pedder, 2005: Errors in dynamical fields inferred from oceanographic cruise data: Part I. The impact of observation errors and the sampling distribution. J. Mar. Syst., 56 (3-4), 317-333.

Goswami, B., and D. Sengupta, 2003: A note on the deficiency of ncep/ncar reanalysis surface winds over the equatorial Indian Ocean. J. Geophys. Res., 108, 3124, doi:10.1029/2002JC001497.
Grumet, N., T. Guilderson, and R. Dunbar, 2002: Meridional transport in the Indian Ocean traced by coral radiocarbon. J. Mar. Res., 60, 725-742.

Hammersley, J., and D. Handscomb, 1975: Monte Carlo Methods. Taylor \& Francis, 20 pp.

Hastenrath, S., 1982: On meridional heat transports in the world ocean. J. Phys. Oceanogr., 12, 922-927.

- 2000: Zonal circulations over the equatorial Indian Ocean. J. Climate, 13, 2746-2756.

— hydrosphere-atmosphere system in the Indian Ocean sector. J. Geophys. Res., 98 (C4), 6869-6881.

_ ocean in the equatorial zone: A synthesis. Int. J. Climatol., 24, $1601-1612$.

Hernández-Guerra, A., E. Fraile-Nuez, F. López-Laatzen, A. Martínez, G. Parrilla, and P. Velez-Belchí, 2005: Canary Current and North Equatorial Current from an inverse model. J. Geophys. Res., 110, C12019, doi:10.1029/2005JC003032.

— Argo data to investigate the meridional overturning circulation in the North Atlantic. Deep-Sea Res. I, 57, 29-36.

Hsiung, J., 1985: Estimates of global oceanic meridional heat transport. J. Phys. Oceanogr., 15, 1405-1413.

Joyce, T., 1988a: Wind-driven cross-equatorial flow in the Pacific Ocean. J. Phys. Oceanogr., 18, 19-24.

_ 1988b: On the wind-driven cross-equatorial flow in the Atlantic Ocean. J. Phys. Oceanogr., 18, 793-799.

Knox, R., 1976: On a long series of measurements of Indian Ocean equatorial currents near Addu Atoll. Deep Sea Res. Oceanogr. Abstr., 23, 211-221.

Large, W., and S. Pond, 1981: Open ocean momentum flux measurements in moderate to strong winds. J. Phys. Oceanogr., 11, 324-336.

Leetmaa, A., H. Rossby, P. Saunders, and P. Wilson, 1980: Subsurface circulation in the Somali Current. Science, 209, 590-592.

_ D. Quadfasel, and D. Wilson, 1982: Development of the flow field during the onset of the Somali Current, 1979. J. Phys. Oceanogr., 12, 1325-1342.

Levitus, S., 1988: Ekman volume fluxes for the world ocean and individual ocean basins. J. Phys. Oceanogr., 18, 271-279.

Loschnigg, J., and P. Webster, 2000: A coupled ocean-atmosphere system of SST modulation for the Indian Ocean. J. Climate, 13, 3342-3360.

Luyten, J., M. Fieux, and J. Gonella, 1980: Equatorial currents in the western Indian Ocean. Science, 209, 600-602.

Masumoto, Y., H. Hase, Y. Kuroda, H. Matsuura, and K. Takeuchi, 2005: Intraseasonal variability in the upper layer currents observed in the eastern equatorial Indian Ocean. Geophys. Res. Lett., 32, L02607, doi:10.1029/2004GL021896.

Maximenko, N., P. Niler, M. Rio, O. Melnichenko, L. Centurion, D. Chambers, V. Zlotnichi, and B. Galperin, 2009: Mean dynamic topography of the ocean derived from satellite and drifting buoy data using three different techniques. J. Atmos. Oceamic Technol., 26, 1910-1919.

McDonagh, E., H. Bryden, B. King, and R. Sanders, 2008: The circulation of the Indian Ocean at 32 S. Prog. Oceanogr., 79, 20-36.

McPhaden, M., 1982: Variability in the central equatorial Indian Ocean. Part I: Ocean dynamics. J. Mar. Res., 40, 157-176.

Meyers, G., 1996: Variation of Indonesian throughflow and the El Niño-Southern Oscillation. J. Geophys. Res., 101 (C5), 12 255-12 263. 
Murty, V., and Coauthors, 2000: Seasonal variability of upper-layer geostrophic transport in the tropical Indian Ocean during 1992-1996 along TOGA-I XBT tracklines. Deep-Sea Res. I, 47, 1569-1582.

Pedder, M., 1993: Interpolation and filtering of spatial observations using successive corrections and Gaussian filters. Mon. Wea. Rev., 121, 2889-2902.

Quadfasel, D., and F. Schott, 1982: Water-mass distributions at intermediate layers off the Somali Coast during the onset of the southwest monsoon, 1979. J. Phys. Oceanogr., 12, 13581372.

_- and G. Cresswell, 1992: A note on the seasonal variability of the South Java Current. J. Geophys. Res., 97 (C3), 3685-3688.

Reppin, J., F. Schott, J. Fischer, and D. Quadfasel, 1999: Equatorial currents and transports in the upper central Indian Ocean: Annual cycle and interannual variability. J. Geophys. Res., 104 (C7), 15 495-15 514.

Reverdin, G., 1987: The upper equatorial Indian Ocean: The climatological seasonal cycle. J. Phys. Oceanogr., 17, 903-927.

Robbins, P., and J. Toole, 1997: The dissolved silica budget as a constraint on the meridional overturning circulation of the Indian Ocean. Deep-Sea Res. I, 44, 879-906.

Roemmich, D., and Coauthors, 2009: Argo: The challenge of continuing 10 years of progress. Oceanography (Wash. D.C.), 22, 46-55.

Schott, F., 1986: Seasonal variation of cross-equatorial flow in the Somali Current. J. Geophys. Res., 91 (C9), 10 581-10 584

— , and D. Quadfasel, 1982: Variability of the Somali Current system during the onset of the southwest monsoon, 1979. J. Phys. Oceanogr., 12, 357-381.

- and J. McCreary, 2001: The monsoon circulation of the Indian Ocean. Prog. Oceanogr., 51, 1-123.

_ J. Swallow, and M. Fieux, 1990: The Somali Current at the equator: Annual cycle of currents and transports in the upper $1000 \mathrm{~m}$ and connection to neighbouring latitudes. Deep-Sea Res. I, 37, 1825-1848.

_- M. Dengler, and R. Schoenefeldt, 2002: The shallow overturning circulation of the Indian Ocean. Prog. Oceanogr., 53, 57-103.

Sengupta, D., R. Senan, B. Goswami, and J. Vialard, 2007: Intraseasonal variability of equatorial Indian Ocean zonal currents. J. Climate, 20, 3036-3055.
Shenoi, S., S. Nasnodkar, N. Rajesh, G. J. Joseph, I. K. Suresh, and A. Almeida, 2009: On the diurnal ranges of Sea Surface Temperature (SST) in the north Indian Ocean. J. Earth Syst. Sci., 118, 483-496.

Shi, W., J. Morrison, and H. Bryden, 2002: Water, heat and freshwater flux out of the northern Indian Ocean in SeptemberOctober 1995. Deep-Sea Res. II, 49 (7-8), 1231-1252.

Sprintall, J., J. Chong, F. Syamsudin, W. Morawitz, S. Hautala, N. Bray, and S. Wijffels, 1999: Dynamics of the South Java current in the Indo-Australian basin. Geophys. Res. Lett., 26 (16), 2493-2496.

— , S. Wijffelsb, R. Molcardc, and I. Jayad, 2010: Direct evidence of the South Java Current system in Ombai Strait. Dyn. Atmos. Oceans, 50, 140-156.

Sultan, E., H. Mercier, and R. Pollard, 2007: An inverse model of the large scale circulation in the South Indian Ocean. Prog. Oceanogr., 74, 71-94.

Sverdrup, H., 1947: Wind-driven currents in a baroclinic ocean; with application to the equatorial currents of the eastern $\mathrm{Pa}$ cific. Proc. Natl. Acad. Sci. USA, 33, 318-326.

Swallow, J., F. Schott, and M. Fieux, 1991: Structure and transport of the east African coastal current. J. Geophys. Res., 96 (C12), 22 245-22 257.

Tomczak, M., and D. Large, 1989: Optimum multiparameter analysis of mixing in the thermocline of the eastern Indian Ocean. J. Geophys. Res., 94 (C11), 16 141-16 149.

- , and J. Godfrey, 2003: Regional Oceanography: An Introduction. Daya Books, $432 \mathrm{pp}$.

Vélez-Belchí, P., A. Hernández-Guerra, E. Fraile-Nuez, and V. Benítez-Barrios, 2010: Changes in the temperature and salinity tendencies of the upper subtropical North Atlantic Ocean at $24.5^{\circ}$ N. J. Phys. Oceanogr., 40, 2546-2555.

Wacongne, S., and R. Pacanowski, 1996: Seasonal heat transport in a primitive equation model of the tropical Indian Ocean. J. Phys. Oceanogr., 26, 2666-2699.

Warren, B., 1999: Approximating the energy tranasport across oceanic sections. J. Geophys. Res., 104 (C4), 7915-7919.

Wyrtki, K., 1973: An equatorial jet in the Indian Ocean. Science, 181, 262-264.

You, Y., and M. Tomczak, 1993: Thermocline circulation and ventilation in the Indian Ocean derived from water mass analysis. Deep-Sea Res. I, 40, 13-56. 